\title{
NORMATIVE APPROACHES IN MAKING CULTURAL QUARTERS AND ASSESSMENT OF CREATIVE INDUSTRY PARKS IN SHANGHAI
}

\author{
Jane ZHENG* \\ Shanghai Theatre Academy, 630 Huashan Rd, Jingan Qu, Shanghai Shi, 200000, China and \\ Chinese University of Hong Kong, Shatin, N.T., 00852, Hong Kong \\ Received 10 October 2016; accepted 20 April 2017
}

\begin{abstract}
This article aims to synthesize the principles of making cultural quarters in literature and test their applicability in creative industry parks in the Chinese context. Extant literature on creative industry parks in China lacks an evaluation instrument for evaluating the performance of creative industry parks. This research reviews normative theories regarding cultural quarter making and identifies three approaches, namely the area-based approach in cultural quarter design, architectural design principles (tailored to cultural quarters), and a comprehensive framework that comprises three dimensions, i.e., activity, built form, and meaning. These normative approaches were applied to evaluate the quality of creative industry parks that emerged in Shanghai in the recent decade. Qualitative research methods, including on-site reconnaissance, observation, and interview, were adopted. The former two approaches revealed good design practices in Shanghai's creative industry parks. A systematic evaluation of the said parks through a comparative study suggests significant disparity in the dimensions of architectural design and place making. Additionally, indicators of state support for micro and small creative industry companies and arts funding are less applicable in Shanghai. These findings reveal the role of the private sector in constructing a diversified creative environment which was previously enshrined by the state. With these outcomes, this research partially endorses the value of the normative theories to guide the practice of making and evaluating cultural quarters in the Chinese context.
\end{abstract}

Keywords: cultural quarter, creative industry park, Shanghai, historic building reuse, place making, cultural venues.

\section{Introduction}

In the past 15 years, a new generation of office quarters that aims to support tertiary and "creative" industries has emerged in Shanghai. Most of these projects involved the renewal of disused industrial buildings through physical intervention and economic revitalization. Creative industry parks in Shanghai were organically initiated by artists and shaped by succeeding government intervention in 2005. The Shanghai Creative Industry Center, an institution supported by the municipal government designated 75 creative industry parks by 2006 (Figure 1). In the years hence, these creative industry parks has continuously increased and reached 132 by 2016 .

Creative industry parks in China's urban development began to attract increasing scholarly attention in the recent decade. A chief academic focus involves the nature and operation of creative industry parks. Based on findings on the commonalities shared by specific media or cultural sectors of creative industries, Keane $(2007,2011)$ foresees a "new leap forward" from "made in China" to "created in China," contingent on the creative development of Chinese people, technologies, and processes. Creative industry parks accommodate creative industries by providing spaces, facilities, and networks with support. However, Keane (2011) problematizes the relationship between artists and the state in China by examining the functions and governance modes of its creative clusters and the ecology of cultural economy innovation in Chinese policy language. In addition, he recommends a move from intellectual to business circles in pursuit of investment returns. The commercialization of workplaces of cultural and creative industries occurred in the background of development-oriented policies (Lin, 1995; Gong, 2006; Common, 2000). Remarkable spatial and physical transformations transpired in China's urban development

*Corresponding author. E-mail: janezzn@hotmail.com

This is an Open Access article distributed under the terms of the Creative Commons Attribution License (http://creativecommons.org/licenses/by/4.0/), which permits unrestricted use, distribution, and reproduction in any medium, provided the original author and source are credited. 


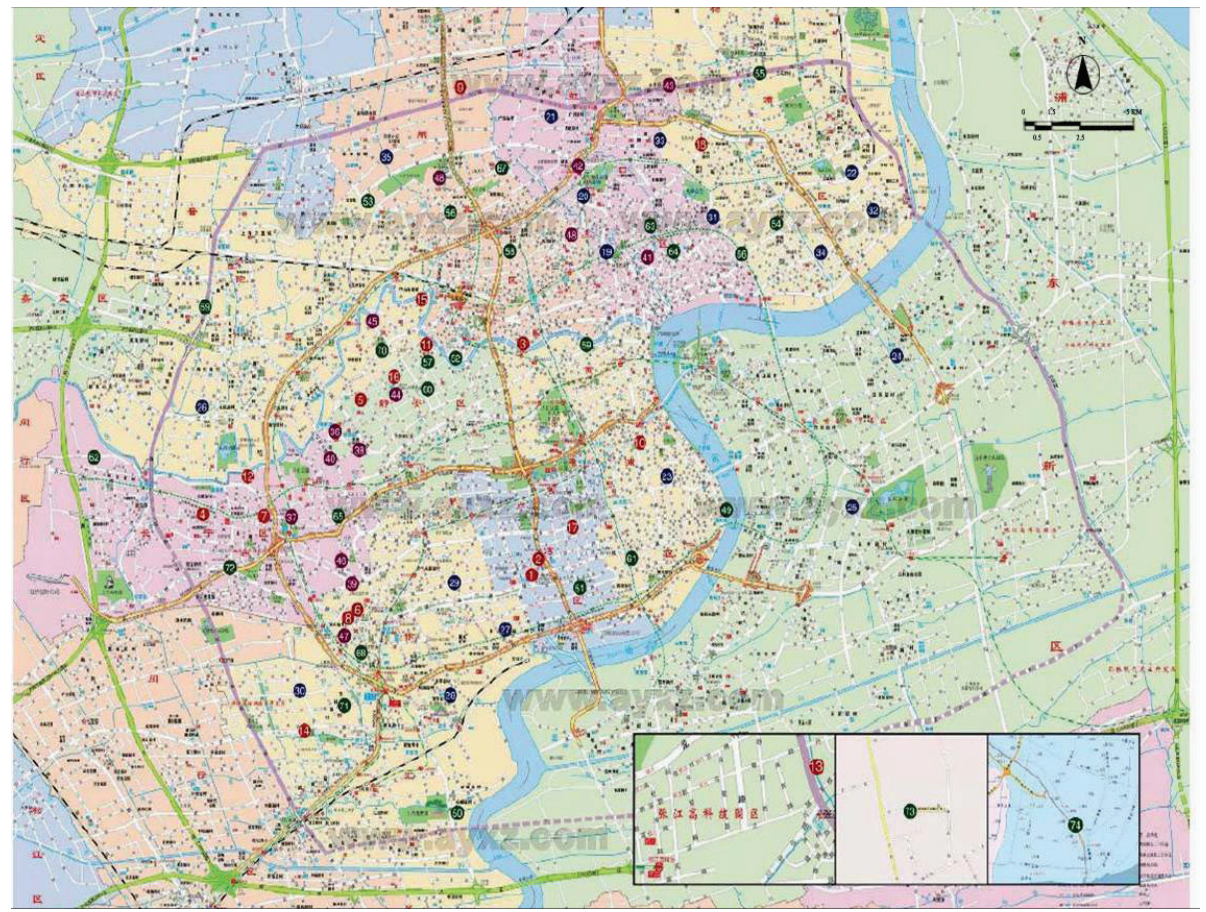

Figure 1. The distribution of creative industry parks in Shanghai

regarding the dimensions of land use and land allocation. The real estate market has significantly grown since the 1990s. A distinctive increase in the number of various "zones" which aim to attract capitals and labors for local development, appears to be another urban phenomenon in the 1990s, known as "zone fever" (Cartier, 2001; Lin, 2007). It has been argued that spontaneously emerged cultural industry spaces were superseded by the local state's zoning approach along with dominant real estate property interests and state-owned enterprises. Likewise, it has been suggested that spontaneously emerged urban cultural spaces were transformed into a new mechanism generating revenues for both urban growth and their own economic benefit. The state was directly involved in the creative industry park businesses rather than serving as independent bodies that effectively control and regulate the market through policies and regulations (Zheng, 2010; O'Connor \& Gu, 2012). Other scholars point out that "creative industries" originated within the mainstream policy discourse in China, and it is doubtful whether China's creative industries can prosper under the condition wherein contemporary art is quarantined. These academics challenge the assumption that the proliferation of cultural districts and clusters in China cultivate a creative climate, and they propose that the progressive function of the "creative industries" discourse frequently claimed by its supporters should not be overlooked (O'Connor \& $\mathrm{Gu}, 2006$ ).

Another major focus of existing research is the social and political conditions of China and the policy context. Kong, Gibson, Khoo, and Semple (2006) explore the extent to which academic and policy knowledge is socially and spatially embedded and circulated. Case studies (e.g., the Red Town) were conducted to reveal the transformation of urban policies leading to the rate of vacated industrial spaces and the functional displacement of industrial areas in the culture-led urban development in Shanghai (Zheng \& Chan, 2013).

In contrast to policy background, evaluating the impact of creative industry clusters receives insufficient emphasis. Most articles highlight the influences of creative industry parks in the economic and social dimensions, whereas the impact of architectural and urban design is rarely assessed. For example, Zheng and Chan (2014) assess the impact of creative industry parks on the cultural milieu for the development of cultural and creative industries in Shanghai. Ineffective support for small- and medium-sized companies is revealed. In an earlier work, Zheng and Chan (2013) explore the interaction between Shanghai's creative industry parks and creative industry networks. Property-led clusters in Shanghai are found to contain inter-company networks; however, most linkages are part of the inter-group networks of companies. Thus, individual companies - not clusters - drive the evolution of creative industry networks. The impact of "creative industry clusters" on urban entrepreneurialism in Shanghai is evaluated. Zheng (2011) argues that such clusters are central in upgrading the entrepreneurial features of the city particularly in attracting business, but their contribution in fostering talent or boosting creative industry entrepreneurship is limited.

Furthermore, the impact of urban and architecture design is rarely evaluated, In particular, the role of architects and urban designers, as well as different contributors in the private and public sectors (e.g., real estate developers, public corporations, and state-owned enterprises) are 
neglected. Less concern is devoted toon architecture and urban design. He and Gebhardt (2013) study the spatial characteristics of creative clusters, although they focus on the distribution of creative clusters. Zheng (2011) analyzes the urban landscape formed by creative industry parks, but the role of different actors in the private sector is not studied. Moreover, a comprehensive evaluative tool for creative industry parks in China is lacking.

This study reviews normative theories that specify methods in making cultural quarters from three perspectives: 1) an area-based approach to cultural quarter design, 2) an architectural design approach for cultural quarters, and 3) a comprehensive approach to cultural quarter-making. These theories are applied in assessing Shanghai's creative industry parks in each section of this paper. The first two sections present the desirable practices of the creative industry parks in Shanghai. In the last section, four selected cases are compared. The research methods in this study mainly involve qualitative methods, such as on-site investigation and observation. A questionnaire survey on the perception of visitors on the quarters is also conducted.

The main argument of this study is twofold. On the one hand, high-quality creative industry parks demonstrate a few desirable architectural design and placemaking practices, which showcase the features of office properties; however, the criteria on supporting micro and small creative industry companies are not applicable. On the other hand, under the same conditions of development, a disparity exists in the quality across the creative industry parks, and overseas developers outperform local developers and state-owned enterprises in Shanghai.

\section{Area-based approach to cultural quarter design}

The initial idea of a cultural quarter was associated with the second and third wave thinking of historic conservation, which introduced an area-based approach to historic conservation. This approach values the entireness of an area, its ad hoc local rhyme, and a managerial approach to growth (i.e., planning the past for the future) (Tiesdell, Oc, \& Heath, 1996; Doratli, 2005). Lynch (1960) defines a district as two-dimensional sections of a city comprising identical components in a degree of density. Thematic continuities are essential to the physical characteristics of districts (Lynch, 1960; Bentley, 1985; Tiesdell et al., 1996; Edelman \& Gaman, 2004).

Prominent examples that illustrate the area-based conservation approach can be identified among the creative industry parks in Shanghai. ${ }^{1}$ These quarters reuse existing historical building stocks while preserving and strengthening the thematic continuity of an endless variety of components (e.g., materials, patterns, rhythms, colors, skylines, articulations, and building ornamentation). Tianzifang is a leading example. This project preserves the

\footnotetext{
1 Approximately $53.2 \%$ of the creative industry parks in Shanghai that comprise old building complexes and open public spaces have applied the area-based preservation approach.
}

history of a residential neighborhood, including the spatial relationships among building height and lane width, characteristic historical building components, original patterns, and rhythms and skylines (Figure 2).

Color is one component that can be employed as a design clue in strengthening the physical feature of a quarter. Several creative industry parks in Shanghai use bright colors to create vibrant zeitgeist images. For example, the designer of the Zhoujiaqiao project used bright yellow dots and lines in contrast with the bright blue background (Figure 3). The Media and Culture Park used bright red to make a dynamic and energetic quarter image (Figure 4). The 98 Creative Park applied three colors, namely, grass green, yellow, and orange, to convey a sense of hope and dynamism (Figure 5).

A strong node creates the effect of "radiation" with a thematic gradient to the nodal point, as well as offers a key public open space for meetings (Lynch, 1960). The $\mathrm{X} 2$ Space includes a carefully designed node at the center. HMA, the architecture company for the X2 Space, designed a fountain at the node, which is embellished with stylistic flower beds made of timber in geometric cubes. Above them are parasols in the same shape as the flower beds. Timber benches and small statues were installed, thereby generating a warm and cozy feeling (Figure 6). In Deng Kunyan's Bingjiang Creative Park, two nodes are laid out: the entrance features a fountain and an eye-catching label (Figure 7), whereas the center node is designed as a circular outdoor "theater" surrounded by one meter-high brick walls, the emptiness of which is in contrast with the quarter's luxuriant vegetation. ${ }^{2}$

Boundaries often sharpen the quarter images and enhance its identity. The creative industry parks in Shanghai have adopted different types of boundary: hard and definite or soft and uncertain (Lynch, 1960). Tonglefang uses three existing intersecting roads, namely, Yuyao Road, Xikang Road, and Haifang Road, as the physical rupture of its edge (Figure 8). For security reasons, most creative industry parks are enclosed or partially enclosed, as well as use walls and gatekeepers to demarcate the scope of the district. Several exceptions involve cases that retain the original open status to allow flexibility for various uses. Tianzifang, an old lane-style residential neighborhood, is an example (Figure 9). In a few cases, offices are located upstairs and the ground floors are open for retails and restaurants to avoid obstacles to pedestrian flow and enhance permeability (e.g., No. 8 Bridge (Figure 10)) (Bentley, 1985).

Large-scale high robustness constitutes another feature of successful creative industry parks in Shanghai. In Tianzifang, the primary use of the quarter includes cultural businesses and activities (e.g., art studios, design companies) in addition to residential uses. The secondary

\footnotetext{
2 Deng Kunyan uses plantation as the main theme of his quarter. His idea is to hide studios and workshops inside luxurious vegetation (Duan \& Cui, 2006).
} 


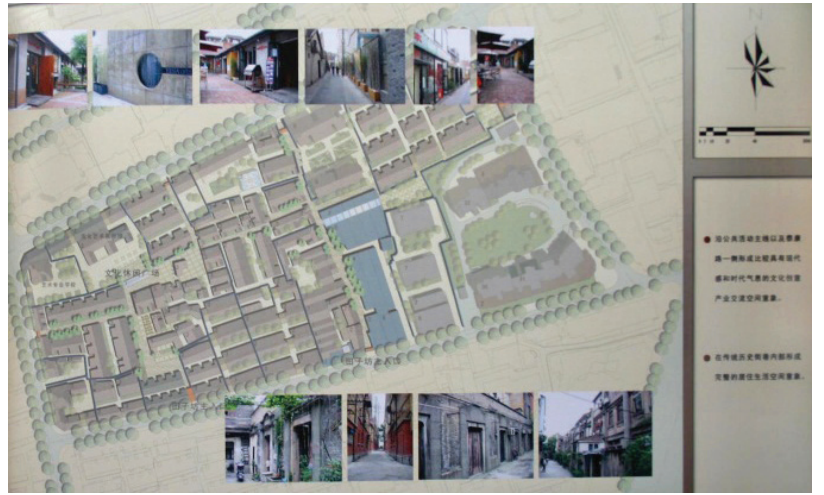

Figure 2. The typology of preserved historical building in Tianzifang Historic District Concept Plan, Shanghai

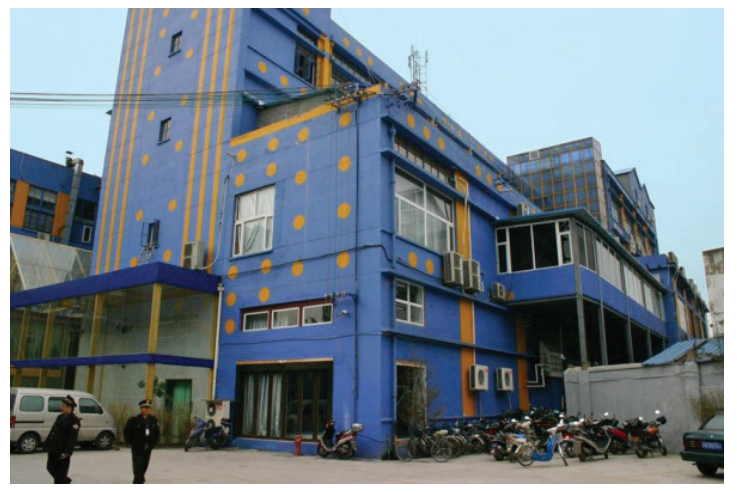

Figure 3. The use of bright color in Zhoujiaqiao, photo by the author, 2006

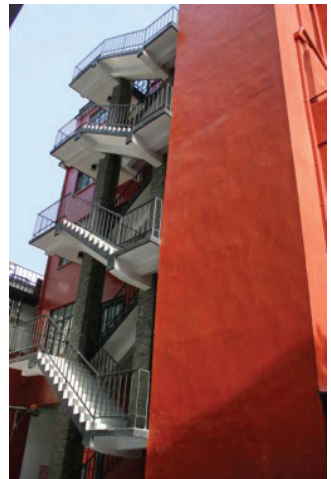

Figure 4. The iron-cast staircases in the Jing'an Culture and Media Park, photo by the author, 2006

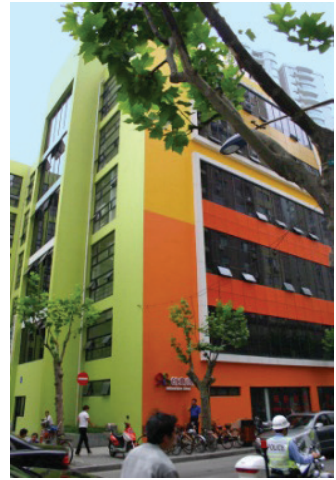

Figure 5. The use of bright color in 98 Creative Park, photo by the author, 2007

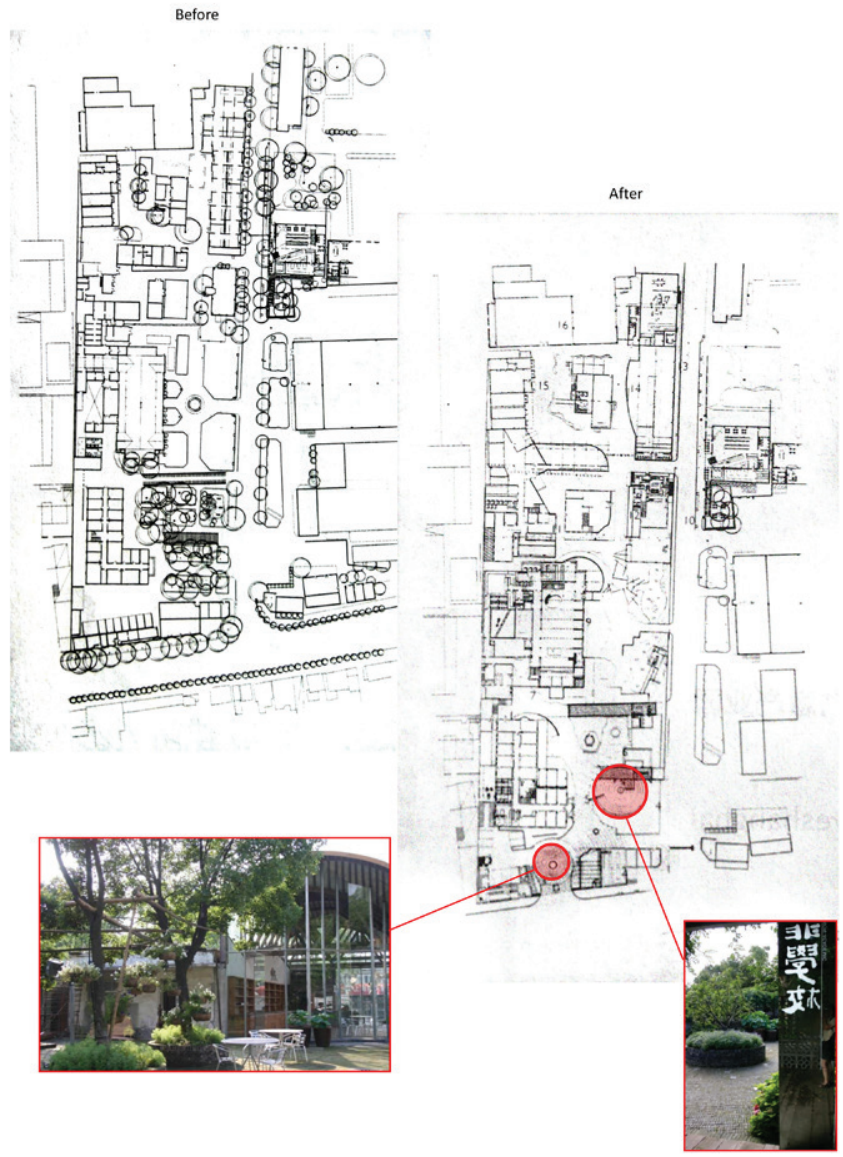

Figure 7. The master plan of the Bingjiang Creative Industry Park (before and after conversion)

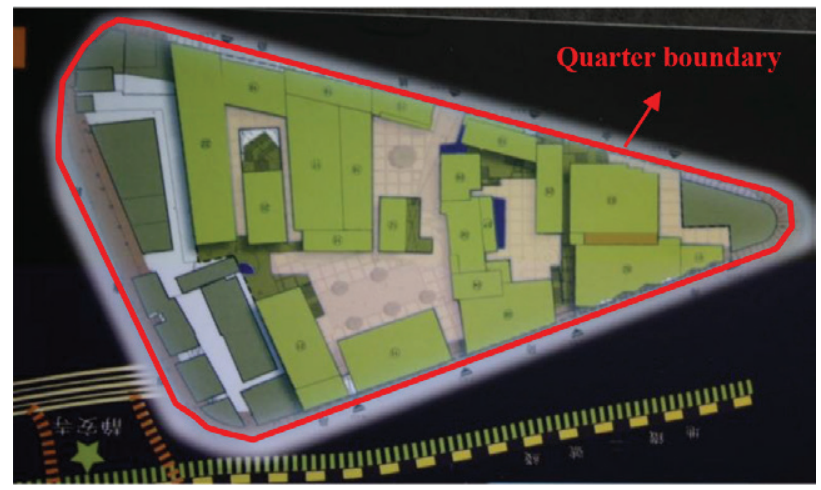

Figure 8. The boundary of Tonglefang, map from the Google map and the developer of the Tonglefang, 2007

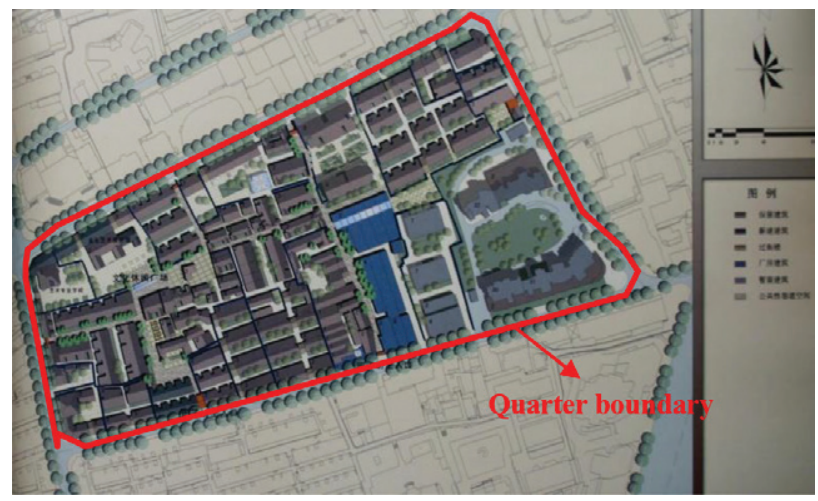

Figure 9. The boundary of the Tianzifang project in the master plan of Tianzifang (Historic and Cultural City Research Centre [HCCRC], 2005, p. 28) 


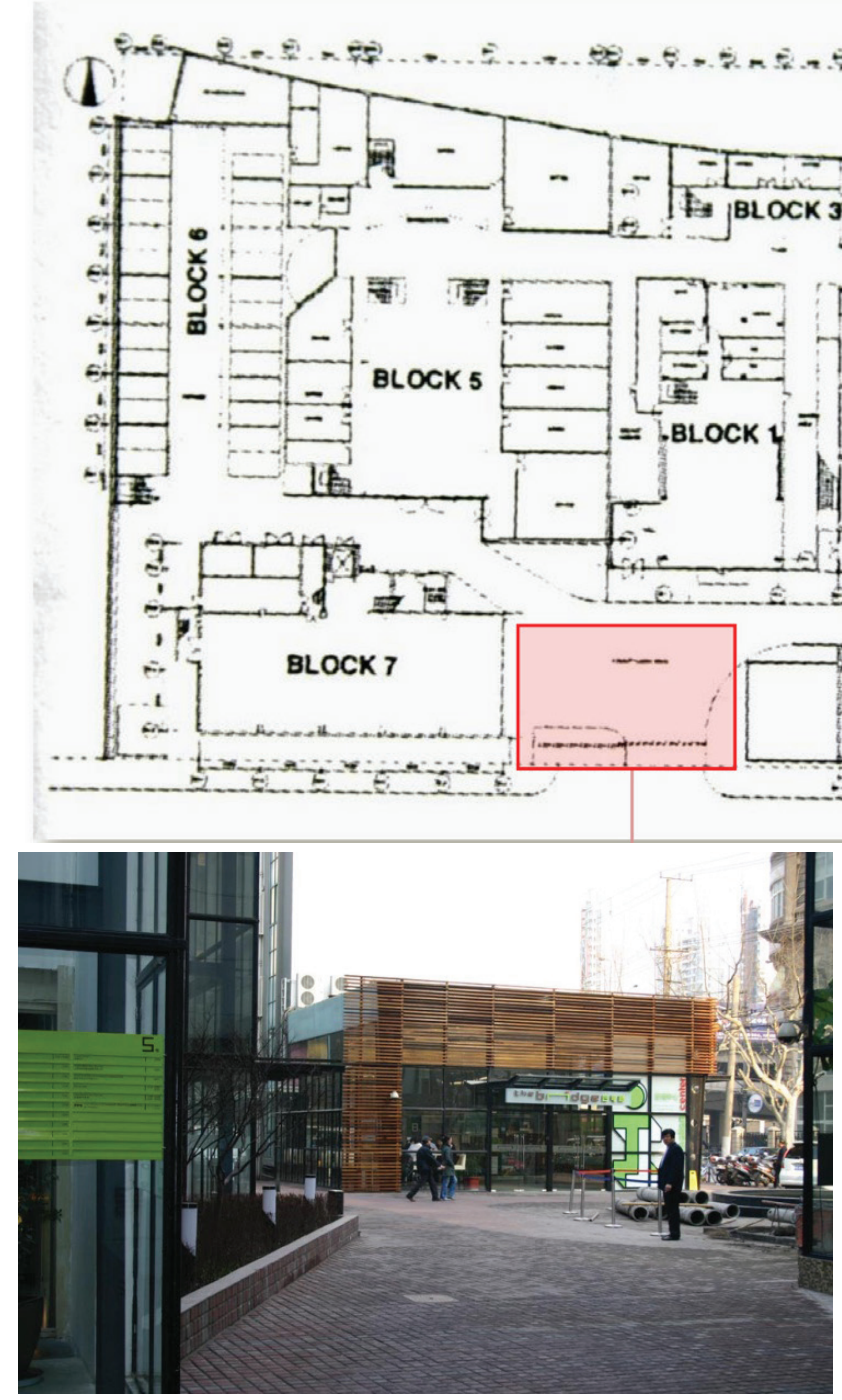

Figure 11. The ground floor being open for retailing in No. 8 Bridge, photo by the author, 2006

use involves cultural consumption (e.g., visitors visiting, playing, retaining, leisure, entertainment and shopping). ${ }^{3}$ At No. 8 Bridge, the ground floor is open for retailing. Large blocks of transparent glasses are mounted on windows and doors to enable pedestrians to see the activities inside (Figure 11). Seats and desks from the shops are arranged with big canopies to shade their visitors comfortably (Figure 12).

\section{Architecture design}

Cultural quarters have a historic continuity of an industrial building style (i.e., emphasizing austerity and solidness)

\footnotetext{
3 Residential uses have performed an important role in the success of Tianzifang. Jacobs (1960) explains that neighborhood is a special urban form where the interweaving of activities and uses is an important factor that leads to success. Tiesdell et al. (1996) agree that residential uses can aid historic quarters own a "living heart," particularly after the shopping and office hours.
}

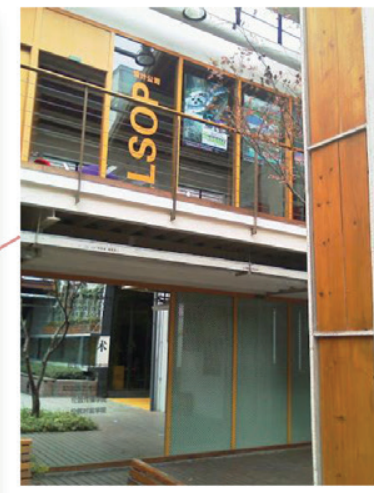

Figure 10. The boundary of the No. 8 Bridge (the master plan and the photo right above)

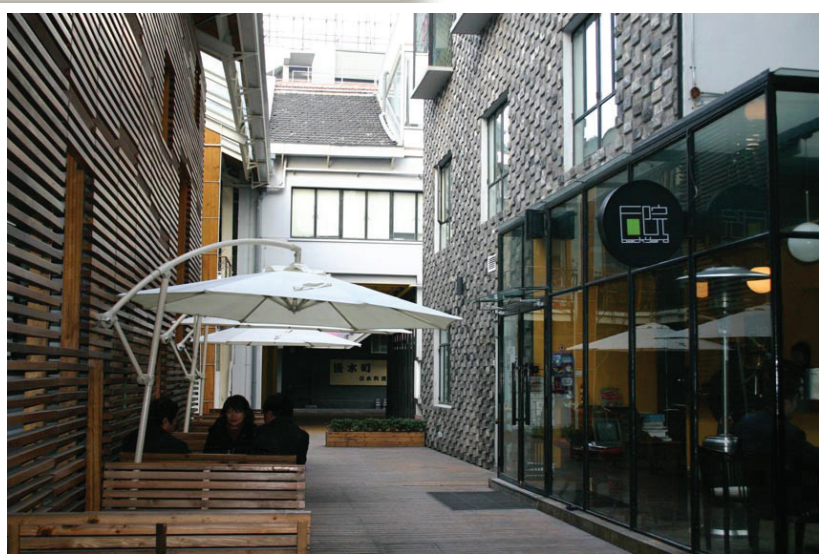

Figure 12. Outdoor bar seats for customers in No. 8 Bridge, photo by the author, 2007

and their characteristic details refer to historical allusions. In many creative industry parks (e.g., No. 8 Bridge, 2577 Creative Garden, Shanghai Sculpture Space, etc.), the interior roof support system is treated as a characteristic industrial building component and is retained in the form of an exposed roof system comprising roof trusses, floor beams, and supports. At the Shanghai International Sculpture Space, the roof is framed by huge trusses, and the girder system spans 72 meters in the south and 180 meters in the north (Figure 13). At the Huzhou Silk Mill, the original complete timber girders that span 13 meters are supported by freestanding timber columns. Iron cast steel doors and staircases are attached externally to the buildings (Figure 14); wire netting interlayer partitions in pitch dark are also employed for decoration. External steel staircases can be found in the Shanghai Fashion Hub, 98 Creative Park (Figure 15), and No. 8 Bridge, among others. At 1933 Old Millfun, upside down umbrella-shaped cement columns, originally designed by Hudec, are incorporated as design components to strengthen the industrial char- 


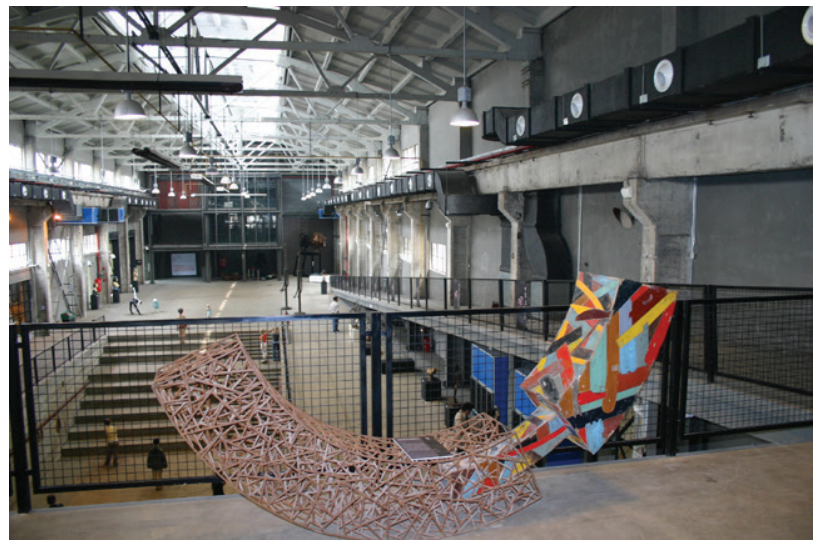

Figure 13. A quenching pool in the Shanghai Sculpture Space (a photo)

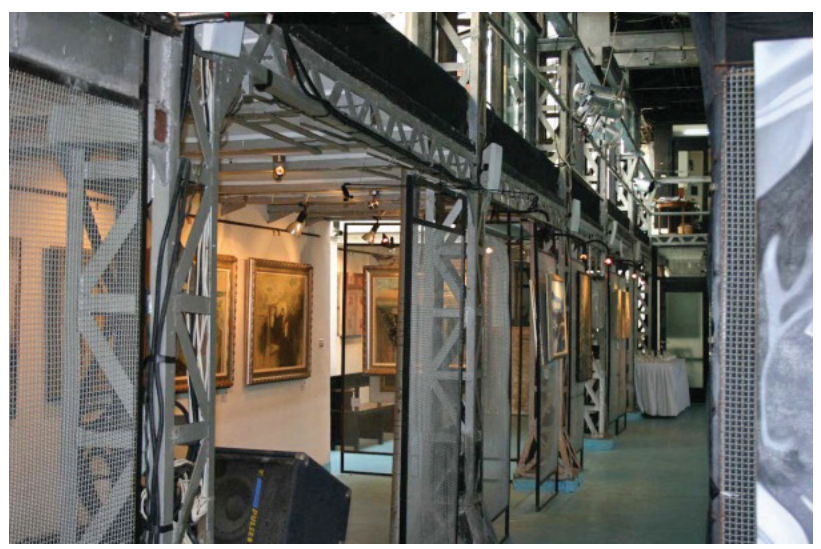

Figure 14. Iron-cast structures in the Er Dongqiang Art Centre in Tianzifang, photo by the author, 2007

acter of the interior space. At the International Sculpture Space, one quenching pool (width: 8.4 meters, length: 24 meters, and depth: 3.6 meters) is dented into the ground, which originally functioned to melt steel, was converted into an interesting and remarkable exhibition site (Figure 18). One huge factory chimney in the 1933 Old Millfun project was converted into a landmark of this project with a strong feeling of the industrial past (Figure 19). In one art gallery in Tianzifang, preserved crane bottles and steel cables hung on the timber girders (Figure 14). These features provoke the imagination of the past industrial era under the guise of a fashionable appearance of their main building facades (Figures 15-17).

The architectural design of Shanghai's creative industry parks is featured using a juxtaposition skill. Rogers (1988) believes that juxtaposing building components from different epochs may result in a harmonious order, which is congruent with the idea that the future is rooted in the memory of the past. Xintiandi is an early example of renewal in Shanghai. However, the creative industry parks adopted the motif of industrial buildings and created a new design style. No. 8 Bridge, the first successful creative industry park project, retains intact building structures to avoid any contrast of spatial characters but juxtaposes different materials on building facades to break the

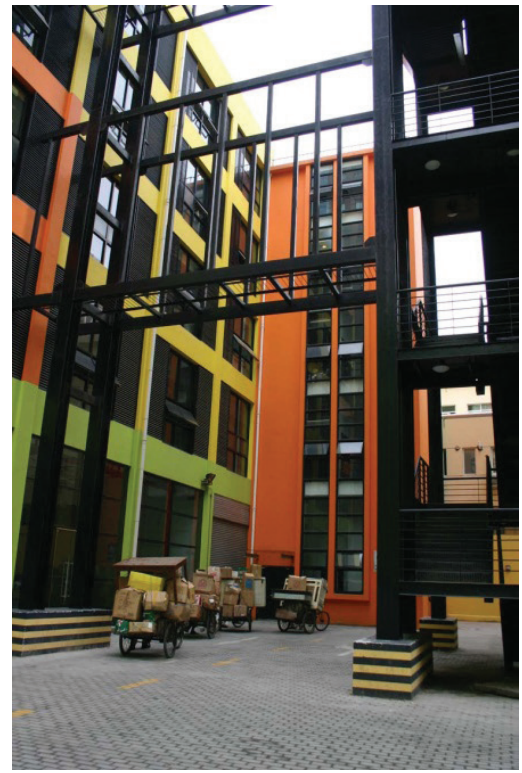

Figure 15. Iron-cast staircases in the 98 Creative Park, photo by the author, 2007

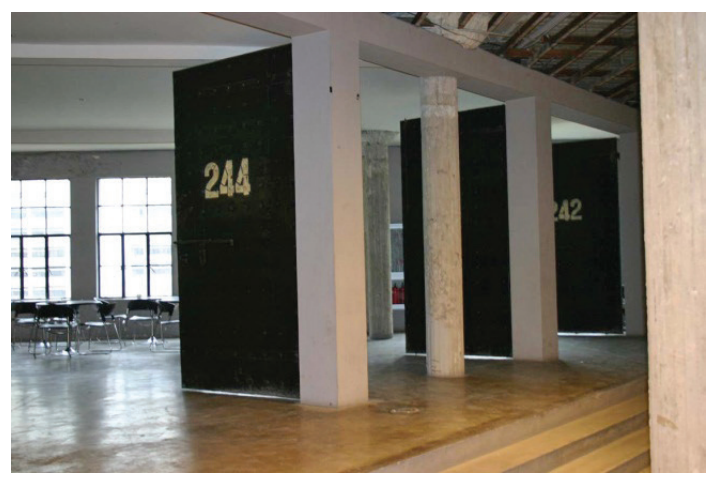

Figure 16. The retained old doors in the Creative Warehouse, photo by the author, 2007

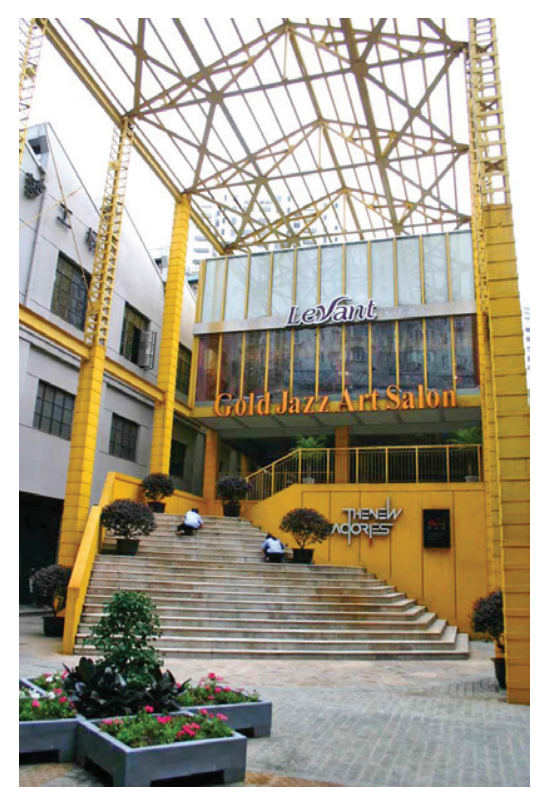

Figure 17. Iron-cast structures in the Er Dongqiang Art Centre in Tianzifang, photo by the author, 2007 

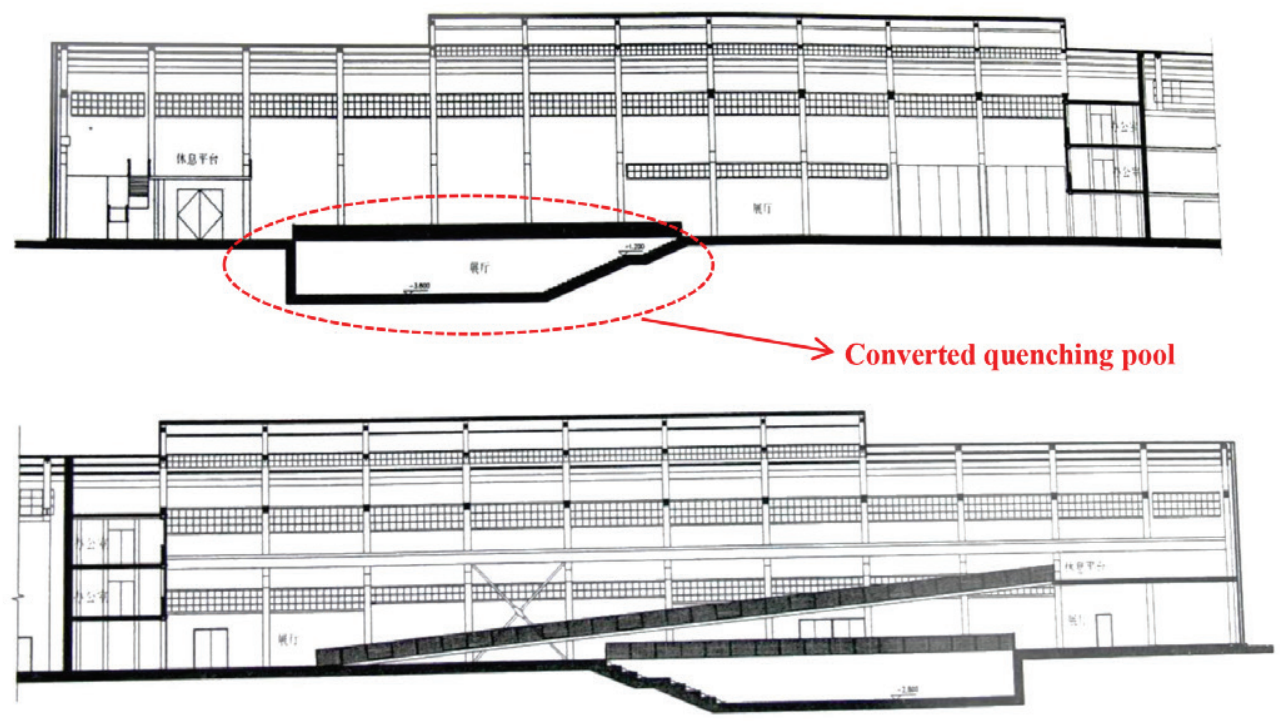

Figure 18. Sections of the main exhibition hall in the Shanghai Sculpture Space
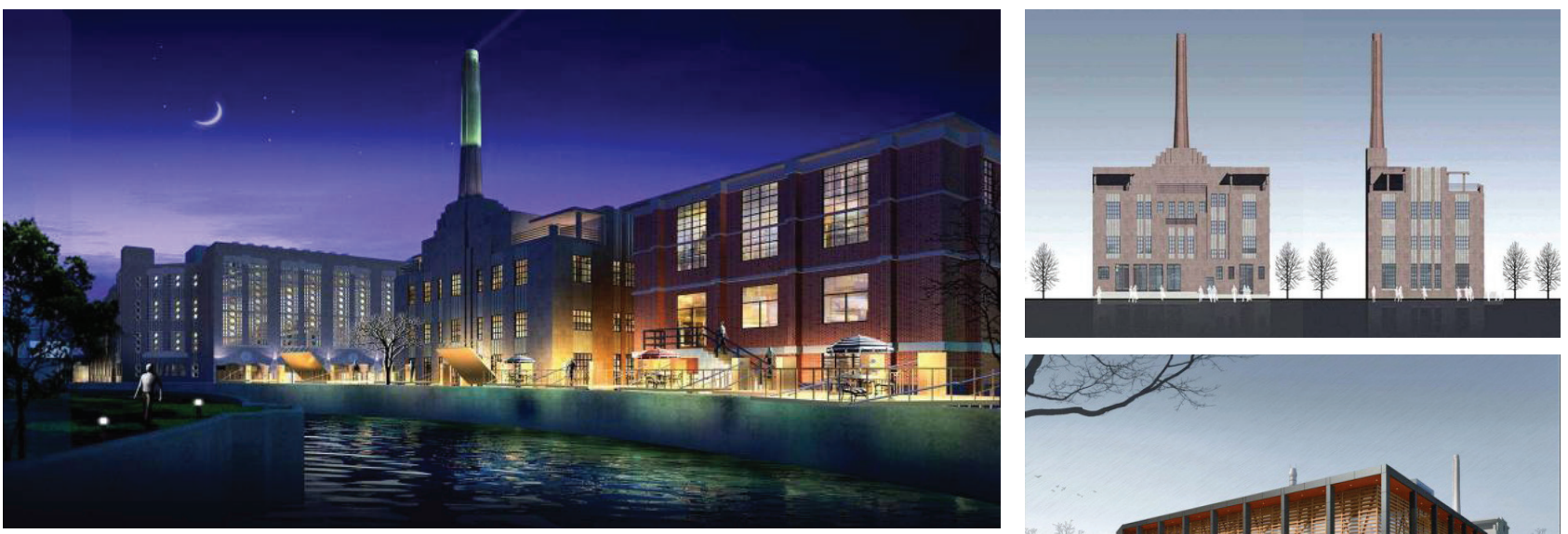

Figure 19. Rendering effects and sections of 1933 Old Millfune, picture provided by the Shanghai Creative Industry Centre, 2007

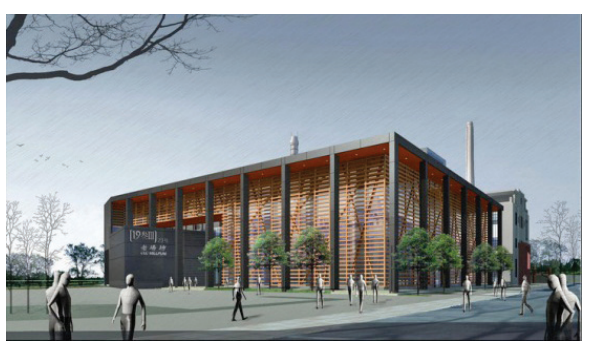

otherwise monotonous continuity of the external walls of industrial buildings. ${ }^{4}$ Blocks of glass, supported by steel frameworks in pitch black, contrast with old bricks on the facades. Bright colors are applied to overpasses that bridge individual buildings, thereby contrasting with large areas of old gray brick walls (Figure 20). These effects signal the vibrancy of the new era. In addition, one type of wire netting panels in white and iron cast panels with chased openwork patterns are attached to the external staircases and the semi-open corridors facing the central square at No. 8 Bridge (Figure 21). Such designs have resulted in spatial layers of the solid and devoid. In the interior design of the Creative Warehouse, the extensive use of glasses, cloth curtains, and colorful electric lighting simultaneously invokes the imagination towards the future, which is

4 Juxtaposing architectural characters rather than spatial characters is a principle recommended in the literature (e.g., Tiesdell et al. 1996).
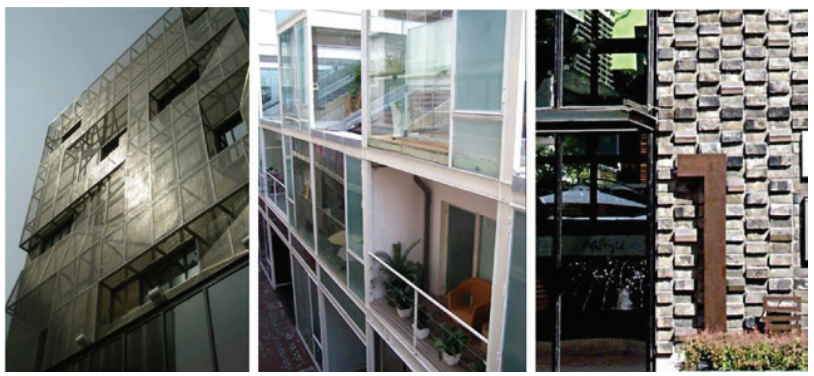

Figure 20. Juxtaposing different materials in building facades in No.8 Bridge, photos from http://images.google.cn/ imgres?imgurl=http://byfiles.storage.msn.com

in sharp contrast with the historic columns and iron cast doors that demarcate the different spaces while maintaining their spatial continuities (Figure 22, Figure 24).

Another new characteristic of the creative industry park design style is the shallow demonstration of history with superficial historical reference and allusions. Xue 

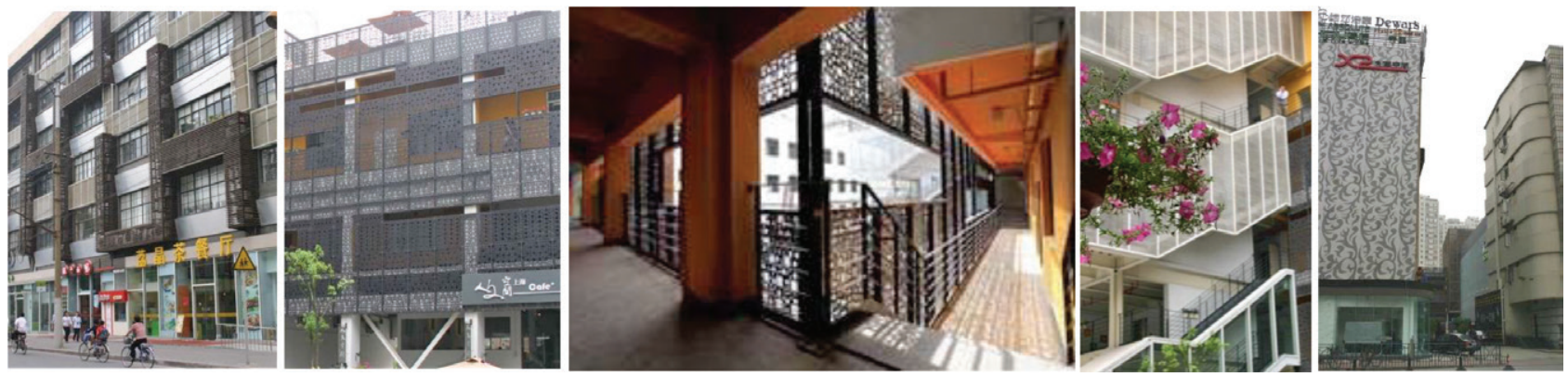

Figure 21. Juxtaposing old and new materials in X2 Space, photo by the author, 2007
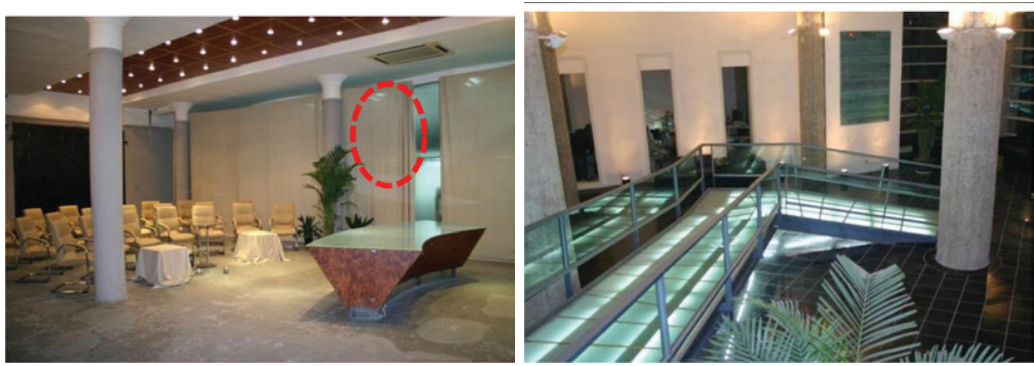

Figure 22. Juxtaposing old and new materials effects in Creative Warehouse, photo by the author, 2007

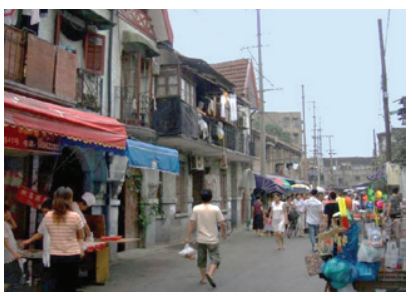

a)

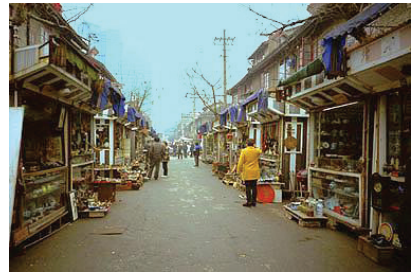

b)

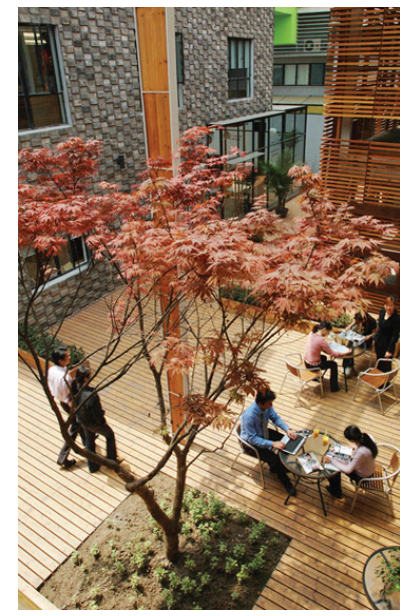

c)
Figure 24. Comparisons between Duolun Road Art District and No. 8 Bridge, photos by the author.

a) Duolun Road; b) Dongtai Road; c) No. 8 Bridge

and Peng (2006) explain that No. 8 Bridge designers use historical buildings to create illusionary images, in which the depth of time is lost and a historical backdrop is created. The design focus is the paths/lanes between building complexes and the lateral facades of the buildings that flank the paths (2006). At the Bingjiang Creative Park designed by Deng Kunyan, the original materials dismantled from old buildings serve as the decorative materials in conversion. The newly added design components, that is, largely transparent glasses and reflective mirrors, are weak in terms of visual impact. Deng explained that he targeted a theatrical stage effect to restore the social order that used to exist in traditional residential rituals (Duan \& Cui, 2007) (Figure 23).

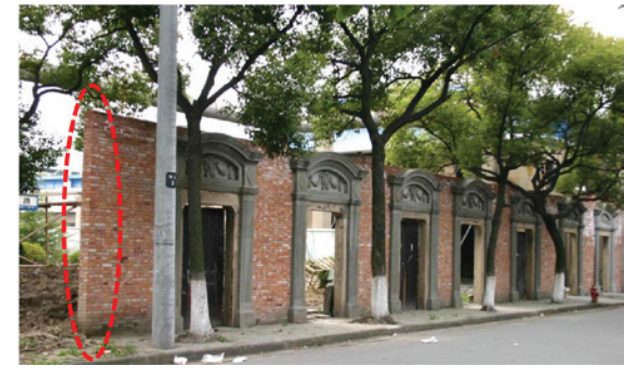

Figure 23. The setting akin to a historic backdrop designed by Deng Kunyan in the Bingjiang Creative Industry Park, photo by the author, 2007

\section{Comprehensive evaluation of cultural districts and comparative study of creative industry parks}

The third approach in making cultural quarters is considerably comprehensive. This approach extends the evaluation to the dimensions of "activity" and "meaning." J. Montgomery reviews a body of literature since Canter (1977) and develops a framework for assessing the conditions and success factors of cultural districts. The first component is "activity," which comprises social, economic, and cultural activities. A good urban place contains diverse primary and secondary uses. These uses are preconditioned by cultural production and cultural consumption with the objective of encouraging active street life (Jacobs, 1960; Comedia \& Gulbenkian, 1991). Cultural activities range from festivals and events, workplaces for artists and cultural production, offices, and studios to arts and media training and education. "Form" refers to the relationship between buildings and spaces. Most indicators for "built form" are derived from Jane Jacobs, Kevin Lynch, and Spiro Kostof. "Meaning" refers to a sense of place, history, and culture, which are important to good urban places (Montgomery, 2003, 2004).

On the basis of the three characteristics of cultural quarters, Roodhouse (2006) develops considerably detailed principles for cultural quarter-making, including "place making," "space design," "activity programming," "built fabric design," and "pedestrian movement." Place making refers to creating a sense of place by subjecting form to function, designing the site with an overall harmonious and partial juxtaposition effects, high permeability and robustness, public open spaces for meeting 


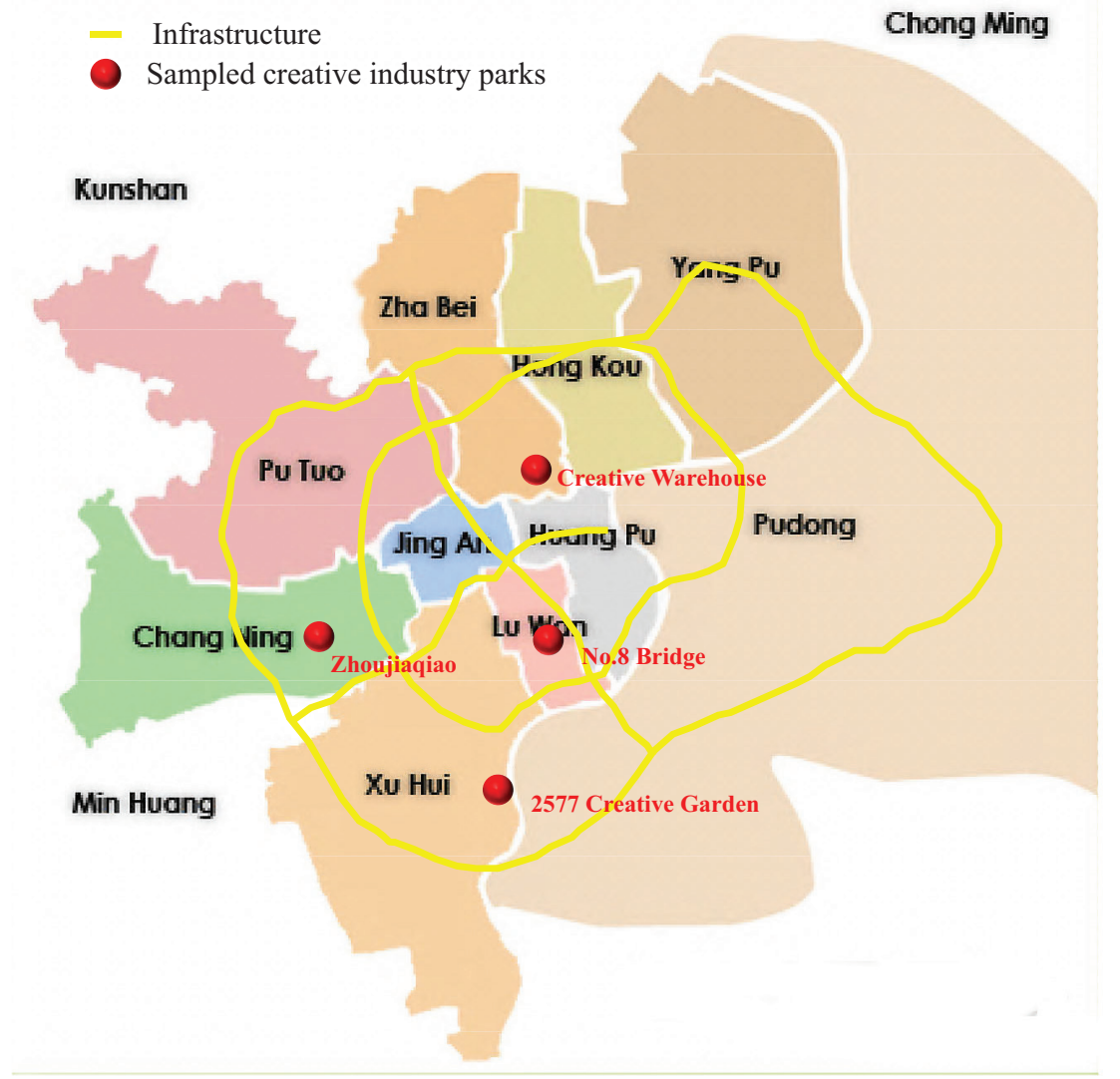

Figure 25. The distribution of 4 sampled creative industry parks in Shanghai

and contact, delightful microclimates, and extensive local meaning. The principle of designing space highlights adaptability in the use of public spaces, as well as elegant and generous senses associated with high culture. To foster vibrant activities, cultural quarters should include active edges and frontages, mix different uses, and distribute activities across day and night. Fabric should be designed in a colorful, delightful, and stimulating manner. Finally, cultural quarters should include strong paths, landmark edges and nodes, and networks that facilitate movement.

To test the applicability of Montgomery's (2003, 2004) framework in the Shanghai context, the current research selected four cases (i.e., No. 8 Bridge, Creative Warehouse, Zhoujiaqiao, and 2577 Creative Garden) for a comparative study (Table 1). The literature on Chinese urban studies suggests that China's urban development is uneven because the party-state holds a pro-growth stance but lacks control on the quality of urban development. Zhu (2004) explains that the weak role of the state in regulating and guiding the real estate market has resulted in the built environment mess. Three major groups of real estate developers, namely, "the state-owned real estate development enterprises," "property developers originating from Hong Kong," and "private-run property development companies," vary in strength and weakness in urban development projects. This difference has resulted in variations in the quality of their development projects (Zhang, 2005; Hsing, 2006; Olds, 2001; Tang \& Liu, 2001). The selected four cases (Figure 25) were developed by Hong Kong developers, local state-owned enterprises called danwei (work unit), and local private developers. This evaluation will not explore the qualifications of the three groups but will evaluate the quality of the creative industry parks in Shanghai. 
Table 1. Applying the evaluation matrix for cultural quarters: Necessary conditions and successful factors (Montgomery, 2003, p. 303)

\begin{tabular}{|c|c|c|c|c|}
\hline & No. 8 Bridge & Creative Warehouse & Zhoujiaqiao & 2577 Creative Garden \\
\hline \multicolumn{5}{|l|}{ 1. Activity } \\
\hline $\begin{array}{l}\text { 1) Diversity of } \\
\text { primary and } \\
\text { secondary land } \\
\text { uses }\end{array}$ & $\begin{array}{l}\text { The primary land use is } \\
\text { for cultural production } \\
\text { and tertiary industries. A } \\
\text { total of } 80 \% \text { of the land is } \\
\text { leased for office use. Over } \\
1 / 3 \text { of the tenants are } \\
\text { transnational design and } \\
\text { consultancy companies. } \\
\text { The relatively high rent } \\
\text { sets a high admission bar } \\
\text { to small businesses. } \\
\text { The secondary land use } \\
\text { is for consumption. This } \\
\text { quarter includes a few } \\
\text { mixed use spaces for bars } \\
\text { and the performing arts. }\end{array}$ & $\begin{array}{l}\text { The primary land use is } \\
\text { for cultural production. A } \\
\text { total of } 60 \% \text { of the land is } \\
\text { leased for office use. The } \\
\text { majority of the tenants } \\
\text { are middle and large } \\
\text { transnational architecture } \\
\text { design companies. } \\
\text { Approximately } 16 \% \text { are on } \\
\text { relatively small scales. } \\
\text { The remaining spaces } \\
\text { have been converted into } \\
\text { spaces for exhibition and } \\
\text { presentation. } \\
\text { The open rooftop floor is } \\
\text { for restaurants and leisure } \\
\text { services. }\end{array}$ & $\begin{array}{l}\text { Half of the site } \\
\text { spaces accommodate } \\
\text { companies of tertiary } \\
\text { industries, cultural } \\
\text { businesses, and } \\
\text { individual artists. One } \\
\text { building standing in the } \\
\text { south is occupied by one } \\
\text { single company tenant. } \\
\text { All the frontage spaces } \\
\text { are leased to restaurants. } \\
\text { Consumption- related } \\
\text { uses account for the } \\
\text { other half of land uses. }\end{array}$ & $\begin{array}{l}\text { The quarter has } 70 \\
\text { building complexes. In } \\
\text { the original plan, seven } \\
\text { functional areas were } \\
\text { zoned: two office quarters } \\
\text { specializing in design, two } \\
\text { office quarters specializing } \\
\text { in art consultation and } \\
\text { advertising, one business } \\
\text { conference center, one art } \\
\text { center, and restaurants. The } \\
\text { central courtyard displays } \\
\text { outdoor sculptures. } \\
\text { According to the plan, } \\
\text { the quarter is oriented } \\
\text { as a mixed use quarter } \\
\text { comprising office, trading, } \\
\text { commerce, and leisure uses. }\end{array}$ \\
\hline $\begin{array}{l}\text { 2) Extent and } \\
\text { variety of cultural } \\
\text { venues }\end{array}$ & $\begin{array}{l}\text { Cultural venues are } \\
\text { divided into four types: } \\
\text { 1) } 40 \% \text { of the land serves } \\
\text { as workplaces for cultural } \\
\text { production; } \\
\text { 2) } 20 \% \text { are for small } \\
\text { restaurants and coffee } \\
\text { bars; } \\
\text { 3) } 20 \% \text { are for } \\
\text { representation/exhibition } \\
\text { spaces (e.g., exhibition } \\
\text { halls at Building No. } 1 \\
\text { and Building No. } 5 \text {; and } \\
4 \text { ) } 20 \% \text { are public open } \\
\text { spaces. The courtyard } \\
\text { (called "rear quarter") } \\
\text { behind Building No. } \\
1 \text { comprises a long } \\
\text { corridor paved with } \\
\text { timber (Ground floor } \\
\text { area (GFA): } 150 \text { square } \\
\text { meters). This structure is } \\
\text { adaptable to any type of } \\
\text { performing arts. }\end{array}$ & $\begin{array}{l}\text { Cultural venues are } \\
\text { divided into four types: } \\
\text { 1) offices; } \\
\text { 2) public spaces on } \\
\text { the second floor } \\
\text { for exhibition, } \\
\text { public meetings, } \\
\text { and presentations } \\
\text { (approximately } 120 \text { square } \\
\text { meters); } \\
\text { 3) a reception hall located } \\
\text { on the ground floor for } \\
\text { cultural events; and } \\
\text { 4) a terrace on the top } \\
\text { floor for outdoor cultural } \\
\text { events. The iron cast deck } \\
\text { can be used as a theatrical } \\
\text { stage for performances. }\end{array}$ & $\begin{array}{l}\text { A total of } 60 \% \text { of the } \\
\text { land is for studio and } \\
\text { office use by individual } \\
\text { artists and creative } \\
\text { industry firms. The } \\
\text { rest are devoted to } \\
\text { cultural exchanges and } \\
\text { presentations. }\end{array}$ & $\begin{array}{l}\text { Two types of public cultural } \\
\text { venues are located in this } \\
\text { quarter: a cultural center } \\
\text { (the actual function of the } \\
\text { center is not specified) and } \\
\text { an open central plaza for } \\
\text { outdoor art exhibitions and } \\
\text { performances. The rest are } \\
\text { leased for office and studio } \\
\text { use. }\end{array}$ \\
\hline $\begin{array}{l}\text { 3) Presence of an } \\
\text { evening economy, } \\
\text { including café } \\
\text { culture }\end{array}$ & $\begin{array}{l}\text { The majority of the } \\
\text { restaurants and bars in } \\
\text { this quarter (e.g., Luna, } \\
\text { Y Beauty Inc. Aroma } \\
\text { Coffee, Rear Courtyard } \\
\text { Coffee) conduct their } \\
\text { businesses in the evening. } \\
\text { These establishments are } \\
\text { often closed after 23:00. } \\
\text { They attract white collar } \\
\text { workers and become } \\
\text { a scene of the local } \\
\text { nighttime economies. } \\
\text { Lighting works to enhance } \\
\text { the sense of evening } \\
\text { economy. }\end{array}$ & $\begin{array}{l}\text { Not open to the public } \\
\text { for evening economies. } \\
\text { However, irregular } \\
\text { cultural activities are held } \\
\text { in the evening. }\end{array}$ & $\begin{array}{l}\text { The frontages are leased } \\
\text { to restaurants, which } \\
\text { conduct their businesses } \\
\text { in the evening. However, } \\
\text { they are separated from } \\
\text { this quarter; hence, they } \\
\text { fail to invigorate the } \\
\text { evening economy of the } \\
\text { quarter. }\end{array}$ & $\begin{array}{l}\text { Restaurants and bars are } \\
\text { located inside this quarter } \\
\text { and not at the frontages. } \\
\text { Moreover, the quarter is } \\
\text { planned mainly for office } \\
\text { use and is inaccessible to } \\
\text { the public. No evident } \\
\text { evening economy is present } \\
\text { in this quarter. }\end{array}$ \\
\hline
\end{tabular}


Continue of Table 1

\begin{tabular}{|c|c|c|c|c|}
\hline & No. 8 Bridge & Creative Warehouse & Zhoujiaqiao & 2577 Creative Garden \\
\hline $\begin{array}{l}\text { 4) Strength } \\
\text { of small-firm } \\
\text { economy, } \\
\text { including creative } \\
\text { businesses (the } \\
\text { indicator of small } \\
\text { firm in cultural } \\
\text { sector included) }\end{array}$ & $\begin{array}{l}\text { The majority of this } \\
\text { quarter's tenants are } \\
\text { large transnational firms, } \\
\text { profitable real estate } \\
\text { properties, development } \\
\text { consultancy companies, } \\
\text { and architecture design } \\
\text { companies. This quarter } \\
\text { is not a place for small } \\
\text { firms. }\end{array}$ & $\begin{array}{l}\text { This quarter has over } \\
20 \text { small firm tenants, } \\
\text { most of which specialize } \\
\text { in advertising. Large } \\
\text { companies are dedicated } \\
\text { to architectural design. } \\
\text { Jobs provided by small } \\
\text { companies account for } \\
16 \% \text { of all employment in } \\
\text { this quarter. }\end{array}$ & $\begin{array}{l}\text { Over } 20 \text { firm tenants } \\
\text { and individual artists } \\
\text { work across a wide } \\
\text { range of creative } \\
\text { industry sectors. } \\
\text { Their professional } \\
\text { specializations are } \\
\text { not restrained within } \\
\text { the scope of creative } \\
\text { industries. }\end{array}$ & $\begin{array}{l}\text { This quarter has over } 10 \\
\text { firm tenants, most of which } \\
\text { are large commercial and } \\
\text { trading companies. The } \\
\text { majority of the creative } \\
\text { industry firms specialize in } \\
\text { profitable professions, such } \\
\text { as architecture, design, and } \\
\text { consultancy. }\end{array}$ \\
\hline $\begin{array}{l}\text { 5) Access to } \\
\text { education } \\
\text { providers (arts } \\
\text { and media } \\
\text { training and } \\
\text { education } \\
\text { included) }\end{array}$ & $\begin{array}{l}\text { Overseas universities } \\
\text { (e.g., London University) } \\
\text { establish admission offices } \\
\text { in this quarter but no } \\
\text { training or education } \\
\text { programs are offered. } \\
\text { Several middle and } \\
\text { vocational schools are } \\
\text { located near the quarter } \\
\text { but no evidence suggests a } \\
\text { social connection between } \\
\text { this quarter and these } \\
\text { schools. }\end{array}$ & $\begin{array}{l}\text { No education or training } \\
\text { institutions are located } \\
\text { in this quarter or in its } \\
\text { vicinity. }\end{array}$ & $\begin{array}{l}\text { This quarter excludes } \\
\text { education or training } \\
\text { institutions on site. } \\
\text { One university is } \\
\text { located in proximity but } \\
\text { limited connection is } \\
\text { determined between the } \\
\text { two institutions. }\end{array}$ & $\begin{array}{l}\text { As per the original plan, } \\
\text { this quarter was originally } \\
\text { oriented to support } \\
\text { advertising firms. A few } \\
\text { education and training } \\
\text { organizations are located in } \\
\text { this quarter as well. }\end{array}$ \\
\hline $\begin{array}{l}\text { 6) Presence of } \\
\text { festivals and } \\
\text { events }\end{array}$ & $\begin{array}{l}\text { Three to four cultural } \\
\text { festivals, art exhibitions, } \\
\text { and other cultural } \\
\text { activities are hosted every } \\
\text { year. Flagship activities are } \\
\text { exemplified by the } 2005 \\
\text { Shanghai International } \\
\text { Fashion Festival, French } \\
\text { Cultural Week, Italian } \\
\text { Tourism Festival, and } \\
\text { 2006 Creative Industry } \\
\text { Week. }\end{array}$ & $\begin{array}{l}\text { Several flagship cultural } \\
\text { activities are hosted, } \\
\text { including fashion } \\
\text { shows, news shows, and } \\
\text { banquets. }\end{array}$ & $\begin{array}{l}\text { No plan is presented to } \\
\text { host regular festival or } \\
\text { other cultural activities. } \\
\text { In 2005, this quarter } \\
\text { was a co-organizer } \\
\text { of the } 2005 \text { Shanghai } \\
\text { International Creative } \\
\text { Week. }\end{array}$ & $\begin{array}{l}\text { A series of cultural activities } \\
\text { have been hosted since the } \\
\text { opening of this quarter. } \\
\text { These activities are all } \\
\text { covered by the media. }\end{array}$ \\
\hline $\begin{array}{l}\text { 7) Availability } \\
\text { of workspaces } \\
\text { for artists and } \\
\text { low-cost cultural } \\
\text { producers }\end{array}$ & $\begin{array}{l}\text { Rental charge: } 6 \text { to } 8 \text { yuan } \\
\text { per day per square meter; } \\
\text { estate service fee: } 20 \text { yuan } \\
\text { per month. This amount } \\
\text { considerably exceeds } \\
\text { the market average rent } \\
\text { of } 2.5 \text { yuan per day per } \\
\text { square meter (2008 data). } \\
\text { Low-income cultural } \\
\text { and creative firms are } \\
\text { excluded in this quarter. }\end{array}$ & $\begin{array}{l}\text { The rent charge and estate } \\
\text { service fee substantially } \\
\text { exceed the average market } \\
\text { level for office property } \\
\text { rent by } 30 \% \text { (Huang, } \\
2005, \text { p. 10). Low-income } \\
\text { cultural and creative firms } \\
\text { are unable to afford this } \\
\text { rate. }\end{array}$ & $\begin{array}{l}\text { The rent charge ranges } \\
\text { from } 2.7 \text { to } 3.6 \text { yuan per } \\
\text { day per square meter; } \\
\text { estate service fee is } 6 \\
\text { yuan per month. The } \\
\text { rent is relatively low in } \\
\text { the market; hence, many } \\
\text { low-income artists are } \\
\text { based in this quarter. } \\
\text { Moreover, additional } \\
\text { latitudes are afforded } \\
\text { to allow adaptive } \\
\text { partitioning subject to } \\
\text { the tenants' needs. }\end{array}$ & $\begin{array}{l}\text { The rental charge is } 3 \text { to } 4 \\
\text { yuan per day per square } \\
\text { meter; estate service fee is } \\
5 \text { yuan per month, which } \\
\text { is higher than the average } \\
\text { market level. This amount } \\
\text { is also higher than that of } \\
\text { the medium-level office } \\
\text { properties. Large companies } \\
\text { constitute the majority of } \\
\text { the tenants, and low-income } \\
\text { firms are rare. Adaptive } \\
\text { partitioning is also allowed. }\end{array}$ \\
\hline $\begin{array}{l}\text { 8) Managed } \\
\text { workspaces for } \\
\text { office and studio } \\
\text { users }\end{array}$ & $\begin{array}{l}\text { The total GRA is } 12,000 \\
\text { square meters. Except for } \\
\text { public spaces, the average } \\
\text { floor area available to } \\
\text { every firm is } 200 \text { square } \\
\text { meters. The ceiling height } \\
\text { is } 6.5 \text { meters. Inserting } \\
\text { fault floors to expand the } \\
\text { floor area is feasible. }\end{array}$ & Similar to No. 8 Bridge. & Similar to No. 8 Bridge. & $\begin{array}{l}\text { This quarter occupies a } 100 \\
m u \text { area. Upon completion, } \\
\text { the total GRA will reach } \\
40,000 \text { square meters. GRA } \\
\text { of the individual factory } \\
\text { buildings ranges from } 200 \\
\text { square meters to } 1,000 \\
\text { square meters. Using the } \\
6 \text { square meter per worker } \\
\text { standard, each building can } \\
\text { accommodate } 35 \text { to } 170 \\
\text { staff members. A total of } 5 \\
\text { to } 10 \text { meter ceiling height } \\
\text { allows additional floor areas } \\
\text { to be inserted. }\end{array}$ \\
\hline
\end{tabular}


Continue of Table 1

\begin{tabular}{|c|c|c|c|c|}
\hline & No. 8 Bridge & Creative Warehouse & Zhoujiaqiao & 2577 Creative Garden \\
\hline $\begin{array}{l}\text { 9) Location of } \\
\text { arts development } \\
\text { agencies and } \\
\text { companies }\end{array}$ & $\begin{array}{l}\text { No specialized arts } \\
\text { development agencies } \\
\text { or companies are } \\
\text { located in this quarter. } \\
\text { Several government- } \\
\text { backed organizations } \\
\text { (e.g., Industrial } \\
\text { Tourism Developing } \\
\text { Association and Shanghai } \\
\text { Development Association) } \\
\text { are operating on this site. }\end{array}$ & $\begin{array}{l}\text { No specialized arts } \\
\text { development agencies and } \\
\text { companies are located in } \\
\text { this quarter. }\end{array}$ & $\begin{array}{l}\text { Similar to Creative } \\
\text { Warehouse. }\end{array}$ & $\begin{array}{l}\text { Similar to Creative } \\
\text { Warehouse. }\end{array}$ \\
\hline $\begin{array}{l}\text { 10) } \\
\text { Complementary } \\
\text { daytime and } \\
\text { evening uses }\end{array}$ & $\begin{array}{l}\text { Office hours of most } \\
\text { companies: 09:00 to } \\
\text { 18:00. Business hours of } \\
\text { retail shops, restaurants, } \\
\text { and bars: 19:00 to 23:00. } \\
\text { Complementary daytime } \\
\text { and evening use is } \\
\text { evident. }\end{array}$ & $\begin{array}{l}\text { Office use during daytime } \\
\text { is dominant. No clear } \\
\text { complementary daytime } \\
\text { and evening use. }\end{array}$ & $\begin{array}{l}\text { Similar to Creative } \\
\text { Warehouse. }\end{array}$ & $\begin{array}{l}\text { Similar to Creative } \\
\text { Warehouse. }\end{array}$ \\
\hline \multicolumn{5}{|l|}{ 2. Built Form } \\
\hline $\begin{array}{l}\text { 1) Fine- } \\
\text { grain urban } \\
\text { morphology }\end{array}$ & $\begin{array}{l}\text { No. } 8 \text { Bridge preserves the } \\
\text { key spatial relationships } \\
\text { (e.g., the ratio of building } \\
\text { height to street width), } \\
\text { original lanes, building } \\
\text { structures, and roof types. } \\
\text { This project fits into the } \\
\text { existing urban fabrics. } \\
\text { No. } 8 \text { Bridge has created } \\
\text { a new image in the } \\
\text { following aspects. First, } \\
\text { it enhances accessibility } \\
\text { with soft boundary, which } \\
\text { is highly 27). Second, } \\
\text { it provides additional } \\
\text { open spaces (e.g., nodes, } \\
\text { streets, and ground floor } \\
\text { open spaces). Nodes } \\
\text { are highlighted with } \\
\text { fountains and public } \\
\text { art (Figure 27). Third, it } \\
\text { reverses the significance } \\
\text { of spatial components. } \\
\text { The integrity of individual } \\
\text { buildings gives way to } \\
\text { lanes in terms of design } \\
\text { (Xue \& Peng, 2006, p. } \\
\text { 128) (Figure 28). Fourth, } \\
\text { sufficient outdoor } \\
\text { amenities and complete } \\
\text { pedestrianization of } \\
\text { the pavement generate a } \\
\text { sense of place. Benches, } \\
\text { public art, and small-scale } \\
\text { landscape also invigorate } \\
\text { the place (Figure } 28 \text { ). }\end{array}$ & $\begin{array}{l}\text { This project uses a } \\
\text { stand-alone three-story } \\
\text { warehouse. It retains } \\
\text { the external appearance } \\
\text { of the building and } \\
\text { its connectivity to the } \\
\text { outside urban portions. } \\
\text { It does not change urban } \\
\text { morphology but preserves } \\
\text { the style and structure of } \\
\text { the military warehouse. }\end{array}$ & $\begin{array}{l}\text { Conversion in this } \\
\text { project mainly involves } \\
\text { changing the colors of } \\
\text { the building facades } \\
\text { and realigning the } \\
\text { function of open spaces } \\
\text { to create parking areas } \\
\text { and improve on-site } \\
\text { circulation system. } \\
\text { However, accessibility to } \\
\text { this site is not improved. } \\
\text { The project does not } \\
\text { physically change } \\
\text { the original urban } \\
\text { morphology. }\end{array}$ & $\begin{array}{l}2577 \text { Creative Garden used } \\
\text { to be a military production } \\
\text { base in the late 19th } \\
\text { century. The architectures } \\
\text { were solidly designed with } \\
\text { a high degree of closeness. } \\
\text { Its regimenting entry } \\
\text { excludes daily activities on } \\
\text { the street; the two minor } \\
\text { entrances are also small. } \\
\text { Overall, site accessibility is } \\
\text { not high and the image of } \\
\text { this quarter is introverted. } \\
\text { Inside the quarter, the } \\
\text { main streets and paths } \\
\text { retained the original scale, } \\
\text { thereby accommodating the } \\
\text { movement of military traffic } \\
\text { (Figure } 26 \text { ). } \\
\text { Public art and street } \\
\text { furniture are installed in } \\
\text { public spaces. However, } \\
\text { this quarter lacks a } \\
\text { pedestrianized area. } \\
\text { The preserved heritage } \\
\text { buildings on the site } \\
\text { are either stand-alone } \\
\text { individual buildings or } \\
\text { complexes with interior } \\
\text { courtyards. }\end{array}$ \\
\hline
\end{tabular}


Continue of Table 1

\begin{tabular}{|c|c|c|c|c|}
\hline & No. 8 Bridge & Creative Warehouse & Zhoujiaqiao & 2577 Creative Garden \\
\hline $\begin{array}{l}\text { 2) Variety and } \\
\text { adaptability of the } \\
\text { building stock }\end{array}$ & $\begin{array}{l}\text { This quarter comprises } \\
\text { seven buildings } \\
\text { with slightly varying } \\
\text { architectural attributes. } \\
\text { The old factory buildings } \\
\text { of the Automobile Brake } \\
\text { Factory are reused. } \\
\text { This project can hardly } \\
\text { expand because of } \\
\text { the limited available } \\
\text { land in the central } \\
\text { city. Insufficient on- } \\
\text { site parking is another } \\
\text { problem. } \\
\text { Partitioning has been } \\
\text { extensively used in the } \\
\text { interior design, which } \\
\text { simultaneously retains } \\
\text { industrial building } \\
\text { characteristics and } \\
\text { maximizes building } \\
\text { functionality (Figures } 28 \\
\text { and 29). }\end{array}$ & $\begin{array}{l}\text { The range of the building } \\
\text { stock variety is low. } \\
\text { However, the stand-alone } \\
\text { building is considerably } \\
\text { suitable for office use } \\
\text { through successful } \\
\text { conversion, which } \\
\text { focuses on interior public } \\
\text { spaces and office use. } \\
\text { The original industrial } \\
\text { building components } \\
\text { with industrial aesthetic } \\
\text { attributes are preserved. } \\
\text { Adaptive rehabilitation } \\
\text { employs design devices } \\
\text { that contrast old and new } \\
\text { architectural features. } \\
\text { The building interior } \\
\text { is characterized by } \\
\text { continuous public spaces } \\
\text { that are adaptive to } \\
\text { multiple uses (Figure } 30 \text { ). }\end{array}$ & $\begin{array}{l}\text { The concretely built } \\
\text { industrial buildings } \\
\text { are adaptive to interior } \\
\text { partitioning. } \\
\text { The rehabilitation } \\
\text { project of this quarter } \\
\text { generally involved } \\
\text { repainting building } \\
\text { features as a technique } \\
\text { to introduce design } \\
\text { variation to the building } \\
\text { facades. }\end{array}$ & $\begin{array}{l}\text { With over } 100 \text { years } \\
\text { of history, this quarter } \\
\text { comprises } 70 \text { buildings } \\
\text { from different historical } \\
\text { periods. They bear varying } \\
\text { physical and aesthetic } \\
\text { characteristics in terms of } \\
\text { building structures and } \\
\text { spatial features. Among the } \\
70 \text { buildings, } 9 \text { are listed } \\
\text { as historic buildings that } \\
\text { apply strict preservation } \\
\text { regulations. They are less } \\
\text { adaptive. Spatial elements } \\
\text { are mixed, including } \\
\text { courtyards, gardens, and } \\
\text { other open spaces. They are } \\
\text { adaptive to interior design } \\
\text { schemes (Figures 32). }\end{array}$ \\
\hline $\begin{array}{l}\text { 3) Permeability of } \\
\text { the streetscape }\end{array}$ & $\begin{array}{l}\text { The visual permeability } \\
\text { of this quarter is high } \\
\text { primarily because of its } \\
\text { low density (i.e., most } \\
\text { buildings are merely two- } \\
\text { to three-stories high). } \\
\text { It also results from an } \\
\text { open space system that } \\
\text { comprises the entry of } \\
\text { this quarter in the form of } \\
\text { a small plaza connected } \\
\text { to five lanes between } \\
\text { building complexes } \\
\text { (Figure } 27 \text { ). Moreover, } \\
\text { the building frontages } \\
\text { comprise venues for retail } \\
\text { and dining uses, through } \\
\text { which the quarter can } \\
\text { be viewed or accessed by } \\
\text { pedestrians. }\end{array}$ & $\begin{array}{l}\text { The former military use } \\
\text { of the warehouse makes } \\
\text { it physically exclusive } \\
\text { to the public. The walls } \\
\text { are strongly and solidly } \\
\text { built and the windows } \\
\text { are high and small. The } \\
\text { visual permeability of the } \\
\text { streetscape is extremely } \\
\text { low in the Creative } \\
\text { Warehouse. }\end{array}$ & $\begin{array}{l}\text { The entrance to this } \\
\text { quarter is a long } \\
\text { narrow path flanked } \\
\text { by tall walls. Visual } \\
\text { permeability to this } \\
\text { quarter is low. However, } \\
\text { visual permeability } \\
\text { inside the quarter is } \\
\text { high because of an } \\
\text { adequate supply of open } \\
\text { spaces on the site. }\end{array}$ & $\begin{array}{l}\text { The military function of this } \\
\text { quarter separates it from the } \\
\text { surrounding urban fabrics. } \\
\text { The visual permeability of } \\
\text { the streetscape is also low. } \\
\text { However, the permeability } \\
\text { inside the quarter is high } \\
\text { because of adequate open } \\
\text { spaces and low density. }\end{array}$ \\
\hline 4) Legibility & $\begin{array}{l}\text { Legibility is high in } \\
\text { this quarter. A fountain } \\
\text { marks the entrance to the } \\
\text { district. The repetitive use } \\
\text { of design clues and the } \\
\text { contrast of new and old } \\
\text { materials on the building } \\
\text { facades enhance the } \\
\text { legibility of the building } \\
\text { complexes. Moreover, a } \\
\text { sky bridge connects the } \\
\text { first and second phases } \\
\text { of development. It has } \\
\text { become a new landmark } \\
\text { with enhanced legibility } \\
\text { (Figure 33). }\end{array}$ & $\begin{array}{l}\text { The building stands } \\
\text { solidly and steeply, } \\
\text { thereby carving the space } \\
\text { out of the neighborhood. } \\
\text { It is marked by the } \\
\text { sign board of "Sihang } \\
\text { Warehouse" on the } \\
\text { façade. However, the } \\
\text { physical characteristics } \\
\text { of the building are } \\
\text { de-emphasized. } \\
\text { Consequently, the external } \\
\text { legibility of the building is } \\
\text { relatively low (Figure } 34 \text { ). }\end{array}$ & $\begin{array}{l}\text { Bright colors on the } \\
\text { building facade make } \\
\text { the quarter stand out } \\
\text { from the neighborhood. } \\
\text { The legibility of the } \\
\text { quarter is high (Figure } \\
\text { 35). }\end{array}$ & $\begin{array}{l}\text { The entrance to this quarter } \\
\text { is small and the continuous } \\
\text { surrounding walls lack } \\
\text { remarkable features. The } \\
\text { legibility of the quarter } \\
\text { is also low. However, the } \\
\text { large advertising board at } \\
\text { the entrance conveys this } \\
\text { quarter's certain sense of } \\
\text { functionality. }\end{array}$ \\
\hline
\end{tabular}


Continue of Table 1

\begin{tabular}{|c|c|c|c|c|}
\hline & No. 8 Bridge & Creative Warehouse & Zhoujiaqiao & 2577 Creative Garden \\
\hline $\begin{array}{l}\text { 5) Amount and } \\
\text { quality of public } \\
\text { space }\end{array}$ & $\begin{array}{l}\text { Public open space } \\
\text { accounts for } 30 \% \text { of this } \\
\text { quarter's land, including } \\
\text { the plaza at the entrance, } \\
\text { lanes between buildings, } \\
\text { and the rear garden. } \\
\text { Nodes in the quarter mix } \\
\text { the use of performance, } \\
\text { traffic circulation, and } \\
\text { entertainment. In two } \\
\text { building blocks, the } \\
\text { ground floors are open } \\
\text { to the public and are } \\
\text { connected to the outdoor } \\
\text { public open space system. } \\
\text { The aggregate public space } \\
\text { amounts to } 50 \% \text {. } \\
\text { The quality of the public } \\
\text { space is highly improved } \\
\text { through pedestrianization } \\
\text { and installation of } \\
\text { outdoor furniture and } \\
\text { lighting (Figure 27). }\end{array}$ & $\begin{array}{l}\text { Public space accounts } \\
\text { for } 40 \% \text { of land use } \\
\text { (accessible only to } \\
\text { the building users), } \\
\text { comprising a terrace on } \\
\text { the rooftop, mixed-use } \\
\text { indoor lecture rooms, } \\
\text { and exhibition halls } \\
\text { for presentation and } \\
\text { entertainment. The central } \\
\text { exhibition hall is located } \\
\text { on the second floor, which } \\
\text { functions as a platform. } \\
\text { The interior public space } \\
\text { is continuous and the } \\
\text { extensive use of curtains } \\
\text { and light projection } \\
\text { creates layers of space } \\
\text { with illusionary and } \\
\text { imaginary interior effects. }\end{array}$ & $\begin{array}{l}\text { Public space accounts } \\
\text { for } 40 \% \text { of land use, } \\
\text { but the inadequate } \\
\text { design has resulted in } \\
\text { inconsistent physical } \\
\text { form and visual effect. } \\
\text { The central courtyard is } \\
\text { used mainly for parking } \\
\text { instead of cultural } \\
\text { activities, thereby } \\
\text { creating a mess effect. } \\
\text { Coarse cement is applied } \\
\text { as ground pavement, } \\
\text { thereby resulting in a } \\
\text { less user-friendly setting. }\end{array}$ & $\begin{array}{l}\text { Public open space accounts } \\
\text { for a relatively high } \\
\text { percentage of land use, } \\
\text { including wide on-site } \\
\text { paths (the ratio of building } \\
\text { height to path width is low, } \\
\text { thereby leading to a low } \\
\text { degree of visual enclosure } \\
\text { or site vibrancy), central } \\
\text { courtyard, and other on- } \\
\text { site nodes with cultural } \\
\text { landscape views. However, } \\
\text { the nodes are poorly paved } \\
\text { and lack outdoor amenities } \\
\text { (Figure } 27 \text { ); specialized } \\
\text { indoor spaces for cultural } \\
\text { and business uses; } \\
\text { and small courtyards } \\
\text { surrounded by building } \\
\text { complexes. Privatized public } \\
\text { spaces include those for } \\
\text { dining, retailing, leisure, } \\
\text { and entertainment (e.g., } \\
\text { restaurants, bars, and clubs). }\end{array}$ \\
\hline $\begin{array}{l}\text { 6) Active street } \\
\text { frontages }\end{array}$ & $\begin{array}{l}\text { Frontage retail shops, } \\
\text { restaurants, and bars } \\
\text { constitute a vibrant } \\
\text { streetscape. However, } \\
\text { the relatively expensive } \\
\text { merchandise and } \\
\text { services have restrained } \\
\text { the participation } \\
\text { of residents in the } \\
\text { adjacent neighborhoods. } \\
\text { Accordingly, they mainly } \\
\text { serve as visitors. }\end{array}$ & $\begin{array}{l}\text { Although several retail } \\
\text { shops are located at } \\
\text { the frontages, they are } \\
\text { unrelated to this cultural } \\
\text { quarter. }\end{array}$ & $\begin{array}{l}\text { All the frontages are } \\
\text { occupied by restaurants } \\
\text { but they are separate } \\
\text { from this quarter in } \\
\text { terms of design features } \\
\text { and neighborhood } \\
\text { relationship. }\end{array}$ & No street frontage. \\
\hline $\begin{array}{l}\text { 7) People } \\
\text { attractors }\end{array}$ & $\begin{array}{l}\text { The area of No. } 8 \text { Bridge } \\
\text { has a high residential } \\
\text { density and features } \\
\text { old lane residential } \\
\text { buildings and high-rise } \\
\text { residential communities. } \\
\text { Moreover, this area is near } \\
\text { Taikang Road Art Street. } \\
\text { Pedestrians, quarter } \\
\text { visitors, and tenants } \\
\text { have all become people } \\
\text { attractors of this quarter. }\end{array}$ & $\begin{array}{l}\text { With the exception of the } \\
\text { quarter administrative } \\
\text { staff members, the } \\
\text { Creative Warehouse } \\
\text { lacks sufficient people } \\
\text { attractors. }\end{array}$ & $\begin{array}{l}\text { This quarter generally } \\
\text { comprises tenant firm } \\
\text { staff members and } \\
\text { administration staff } \\
\text { members. However, they } \\
\text { cannot be considered } \\
\text { formal people attractors. }\end{array}$ & $\begin{array}{l}\text { This quarter occasionally } \\
\text { holds cultural and business } \\
\text { activities. However, } \\
\text { no evidence suggests } \\
\text { that people have been } \\
\text { incorporated as attractors. }\end{array}$ \\
\hline \multicolumn{5}{|l|}{ 3. Meaning } \\
\hline $\begin{array}{l}\text { 1) Important } \\
\text { meeting and } \\
\text { gathering spaces }\end{array}$ & $\begin{array}{l}\text { At No. } 8 \text { Bridge, public } \\
\text { open spaces, restaurants, } \\
\text { and bars are the meeting } \\
\text { spaces. However, they are } \\
\text { not affordable and are } \\
\text { only partially accessible } \\
\text { to the local neighborhood } \\
\text { because prices are } \\
\text { relatively higher than the } \\
\text { market average. }\end{array}$ & $\begin{array}{l}\text { Public spaces are available } \\
\text { for cultural programs but } \\
\text { are exclusive to building } \\
\text { users. }\end{array}$ & $\begin{array}{l}\text { No well-defined meeting } \\
\text { or gathering places. }\end{array}$ & $\begin{array}{l}\text { No well-defined meeting or } \\
\text { gathering spaces. However, } \\
\text { public open spaces may be } \\
\text { the place for meeting and } \\
\text { gathering under certain } \\
\text { conditions (e.g., cultural } \\
\text { festivals) or in a few specific } \\
\text { venues (e.g., restaurants). }\end{array}$ \\
\hline
\end{tabular}


Continue of Table 1

\begin{tabular}{|c|c|c|c|c|}
\hline & No. 8 Bridge & Creative Warehouse & Zhoujiaqiao & 2577 Creative Garden \\
\hline $\begin{array}{l}\text { 2) Sense of } \\
\text { history and } \\
\text { progress }\end{array}$ & $\begin{array}{l}\text { The original buildings } \\
\text { of the Automobile Brake } \\
\text { Factory were built in the } \\
\text { 1950s and 1960s. The } \\
\text { physical interventions } \\
\text { only involve converting } \\
\text { the disused industrial } \\
\text { buildings. This quarter } \\
\text { design emphasizes the } \\
\text { advancements of the } \\
\text { time by employing old } \\
\text { architectural elements } \\
\text { and new materials on the } \\
\text { building facades. }\end{array}$ & $\begin{array}{l}\text { The external appearance } \\
\text { of the warehouse has } \\
\text { been retained. Inside the } \\
\text { building, the architectural } \\
\text { components originally } \\
\text { designed by Hudec } \\
\text { are either preserved or } \\
\text { incorporated into the new } \\
\text { design through conversion } \\
\text { (e.g., iron cast doors). } \\
\text { The sense of history has } \\
\text { been preserved and the } \\
\text { progress of the era has } \\
\text { been presented. }\end{array}$ & $\begin{array}{l}\text { This quarter's } \\
\text { rehabilitation project } \\
\text { retained the original } \\
\text { building structure and } \\
\text { the small historical } \\
\text { industrial components } \\
\text { (e.g., industrial } \\
\text { apparatus). They } \\
\text { contrast with the new } \\
\text { paint in bright colors } \\
\text { on the building facades, } \\
\text { thereby resulting in a } \\
\text { zeitgeist effect and a } \\
\text { sense of history. }\end{array}$ & $\begin{array}{l}\text { Historic buildings since } \\
\text { the Qing period have been } \\
\text { preserved and converted, } \\
\text { and have become a selling } \\
\text { point of this quarter. } \\
\text { However, as the design } \\
\text { schemes were not well } \\
\text { applied, the actual visual } \\
\text { effects have limited success } \\
\text { in representing the sense } \\
\text { of history and progress. } \\
\text { Historic relics (e.g., shell } \\
\text { and barrel) are preserved } \\
\text { and displayed in the public } \\
\text { space. }\end{array}$ \\
\hline $\begin{array}{l}\text { 3) Area identity } \\
\text { and imagery }\end{array}$ & $\begin{array}{l}\text { The original factory } \\
\text { buildings do not attract } \\
\text { public attention. The } \\
\text { conversion project has } \\
\text { changed the image of the } \\
\text { old factory. No. } 8 \text { Bridge } \\
\text { has developed a new } \\
\text { image with a certain sense } \\
\text { of identity for its residents } \\
\text { (Interview and local } \\
\text { newspaper reports). }\end{array}$ & $\begin{array}{l}\text { Sihang Warehouse is } \\
\text { a heritage building } \\
\text { associated with a } \\
\text { significant local historical } \\
\text { event. However, it has } \\
\text { been used simply for } \\
\text { storage for many years. } \\
\text { The Creative Warehouse } \\
\text { project has evoked } \\
\text { people's memory into } \\
\text { its history. This project } \\
\text { has also contributed in } \\
\text { building the identity and } \\
\text { psychological attachment } \\
\text { of the tenants and } \\
\text { residents (questionnaire } \\
\text { survey). }\end{array}$ & $\begin{array}{l}\text { The Zhoujiaqiao } \\
\text { Creative Park has } \\
\text { changed the original } \\
\text { derelict outlook of the } \\
\text { local neighborhood and } \\
\text { has become a landmark } \\
\text { in the area (Interview } \\
\text { with administration } \\
\text { staff members in the } \\
\text { Zhoujiaqiao Creative } \\
\text { Park, 2006). }\end{array}$ & $\begin{array}{l}\text { This former military } \\
\text { production base established } \\
\text { by Li Hongzhang is an } \\
\text { important heritage site. } \\
\text { However, it has continued } \\
\text { its original function, } \\
\text { which is unknown to the } \\
\text { public, for a long time. } \\
\text { Converting this quarter into } \\
\text { a creative industry park } \\
\text { has regenerated the place } \\
\text { as a new landmark in the } \\
\text { Longhu area. Moreover, the } \\
\text { local cultural components } \\
\text { have contributed to a new } \\
\text { identity or a sense of place } \\
\text { for the quarter. }\end{array}$ \\
\hline $\begin{array}{l}\text { 4) Knowledge- } \\
\text { ability }\end{array}$ & $\begin{array}{l}\text { No. } 8 \text { Bridge is } \\
\text { substantially promoted } \\
\text { via multiple media } \\
\text { outlets (e.g., newspapers, } \\
\text { magazines, TV programs, } \\
\text { and websites). The public } \\
\text { is also informed of this } \\
\text { project via flagship } \\
\text { events (e.g., Shanghai } \\
\text { International Creative } \\
\text { Industry Week, France } \\
\text { Culture Week, etc.). }\end{array}$ & $\begin{array}{l}\text { The Creative Warehouse } \\
\text { is branded and promoted } \\
\text { via various media. It also } \\
\text { holds regular cultural } \\
\text { activities and increases its } \\
\text { popularity. }\end{array}$ & $\begin{array}{l}\text { This quarter assists the } \\
\text { SCIC in holding flagship } \\
\text { events. These branding } \\
\text { exercises have raised the } \\
\text { profile of this quarter. } \\
\text { However, this quarter is } \\
\text { generally unknown in } \\
\text { Shanghai. }\end{array}$ & $\begin{array}{l}\text { This quarter's developer } \\
\text { extensively uses symbolic } \\
\text { capital (i.e., culture and } \\
\text { history of the quarter) } \\
\text { to build its image. The } \\
\text { brochures and websites } \\
\text { of the project are well } \\
\text { designed and informative. }\end{array}$ \\
\hline $\begin{array}{l}\text { 5) Environmental } \\
\text { signifiers }\end{array}$ & $\begin{array}{l}\text { Many building materials } \\
\text { used for conversion are } \\
\text { artistically effective and } \\
\text { environment-friendly but } \\
\text { inexpensive. }\end{array}$ & $\begin{array}{l}\text { Converting solidly built } \\
\text { industrial buildings, such } \\
\text { as this one, has significant } \\
\text { implications in terms of } \\
\text { saving natural resources } \\
\text { for efficient use. }\end{array}$ & $\begin{array}{l}\text { The paint applied } \\
\text { is inexpensive and } \\
\text { environment-friendly. }\end{array}$ & $\begin{array}{l}\text { The original design scheme } \\
\text { for this creative park } \\
\text { aimed to create a pleasant } \\
\text { and quiet environment. } \\
\text { However, such design was } \\
\text { not strictly implemented } \\
\text { and the outcome was } \\
\text { unsatisfactory. }\end{array}$ \\
\hline Comments & $\begin{array}{l}\text { No. } 8 \text { Bridge is an ideal } \\
\text { example of adaptively } \\
\text { reusing historic building } \\
\text { complexes for office } \\
\text { use. This project } \\
\text { creates a stylized and } \\
\text { friendly environment } \\
\text { for businesses, } \\
\text { particularly transnational } \\
\text { corporations. }\end{array}$ & $\begin{array}{l}\text { This project is also a } \\
\text { good example of adapting } \\
\text { historic quarters to } \\
\text { new office use through } \\
\text { conversion and redesign. } \\
\text { The interior public spaces } \\
\text { are well designed for a } \\
\text { mixture of multiple uses } \\
\text { (e.g., exhibition, public } \\
\text { lecture, meeting, and } \\
\text { culture-related activities). }\end{array}$ & $\begin{array}{l}\text { The quality of design } \\
\text { and development of the } \\
\text { Zhoujiaqiao project is } \\
\text { inferior to the previous } \\
\text { two examples. However, } \\
\text { it accommodates many } \\
\text { small firms. } \\
\text { Cultural events have } \\
\text { gained inadequate } \\
\text { support partially } \\
\text { because of the lack of } \\
\text { design techniques. }\end{array}$ & $\begin{array}{l}\text { Using symbolic capital to } \\
\text { increase property values is } \\
\text { the remarkable character } \\
\text { of this project, including } \\
\text { utilizing local history and } \\
\text { culture. However, this } \\
\text { project is inadequate in } \\
\text { terms of urban design and } \\
\text { place-making. } \\
\text { Inherent deficiencies in the } \\
\text { built form of this project } \\
\text { can be identified. }\end{array}$ \\
\hline
\end{tabular}


End of Table 1

\begin{tabular}{|c|c|c|c|c|}
\hline & No. 8 Bridge & Creative Warehouse & Zhoujiaqiao & 2577 Creative Garden \\
\hline Comments & $\begin{array}{l}\text { No. } 8 \text { Bridge has } \\
\text { demonstrated sophisticated } \\
\text { place- making techniques } \\
\text { more than the other } \\
\text { creative industry parks } \\
\text { in Shanghai, as reflected } \\
\text { by the indicators of } \\
\text { "diversity of primary and } \\
\text { secondary land uses," } \\
\text { "extent and variety of } \\
\text { cultural venues," "presence } \\
\text { of an evening economy," } \\
\text { and "festivals and events." } \\
\text { No. } 8 \text { Bridge also has a } \\
\text { better-built form in terms } \\
\text { of variety and quality of } \\
\text { public spaces, legibility, } \\
\text { and active frontages. The } \\
\text { preservation of original } \\
\text { building structures and } \\
\text { the contrast of old and } \\
\text { new components are the } \\
\text { distinctive features of the } \\
\text { new design scheme. } \\
\text { Nevertheless, this } \\
\text { project does not exhibit } \\
\text { considerable sympathy } \\
\text { for the small-firm } \\
\text { economy (including } \\
\text { creative businesses) } \\
\text { and lends limited } \\
\text { support to the growth } \\
\text { of cultural businesses } \\
\text { (i.e., no funding support, } \\
\text { education, or training). }\end{array}$ & $\begin{array}{l}\text { One inherent deficiency } \\
\text { of this project is that the } \\
\text { warehouse is a stand- } \\
\text { alone building, and the } \\
\text { solidly built walls abruptly } \\
\text { separate it from the } \\
\text { external urban fabrics. } \\
\text { A lack of public space } \\
\text { open to the general } \\
\text { public has also limited } \\
\text { permeability and reduced } \\
\text { the variety of cultural } \\
\text { activities. The selling } \\
\text { point of this project is the } \\
\text { interior design that has } \\
\text { created a historical and } \\
\text { contemporary sense of } \\
\text { place. } \\
\text { Similar to No. } 8 \text { Bridge, } \\
\text { limited support has been } \\
\text { provided to the growth of } \\
\text { culture and creativity of } \\
\text { small firms. }\end{array}$ & $\begin{array}{l}\text { The central courtyard is } \\
\text { used for parking and the } \\
\text { frontages were leased } \\
\text { to restaurants without } \\
\text { connection to the } \\
\text { quarter in both senses of } \\
\text { function and design. The } \\
\text { successful application } \\
\text { of bright colors on } \\
\text { the building facades } \\
\text { facilitates the enhanced } \\
\text { legibility of this quarter. } \\
\text { The preservation } \\
\text { of original building } \\
\text { structures and historical } \\
\text { architectural elements } \\
\text { has contributed to the } \\
\text { sense of place. } \\
\text { Relatively low rent } \\
\text { charges make this } \\
\text { quarter considerably } \\
\text { suitable to small cultural } \\
\text { and creative industry } \\
\text { firms. However, this } \\
\text { quarter lacks training } \\
\text { and education support } \\
\text { for cultural businesses. }\end{array}$ & $\begin{array}{l}\text { The original military uses } \\
\text { have left solidly built } \\
\text { walls and small openings, } \\
\text { thereby leading to a lack } \\
\text { of active frontages and } \\
\text { a weak connection with } \\
\text { urban fabrics. The width } \\
\text { of the streets and paths for } \\
\text { military uses has hindered } \\
\text { the project from increasing } \\
\text { density. Failing to retain } \\
\text { the original scheme has } \\
\text { caused incompatibility in } \\
\text { architectural styles on the } \\
\text { site. Cultural activities and } \\
\text { elements are the merits of } \\
\text { this project. } \\
\text { This project is naturally } \\
\text { a business quarter (to } \\
\text { be discussed in the next } \\
\text { chapter), thereby providing } \\
\text { no support for small } \\
\text { cultural and creative } \\
\text { industry firms. }\end{array}$ \\
\hline
\end{tabular}
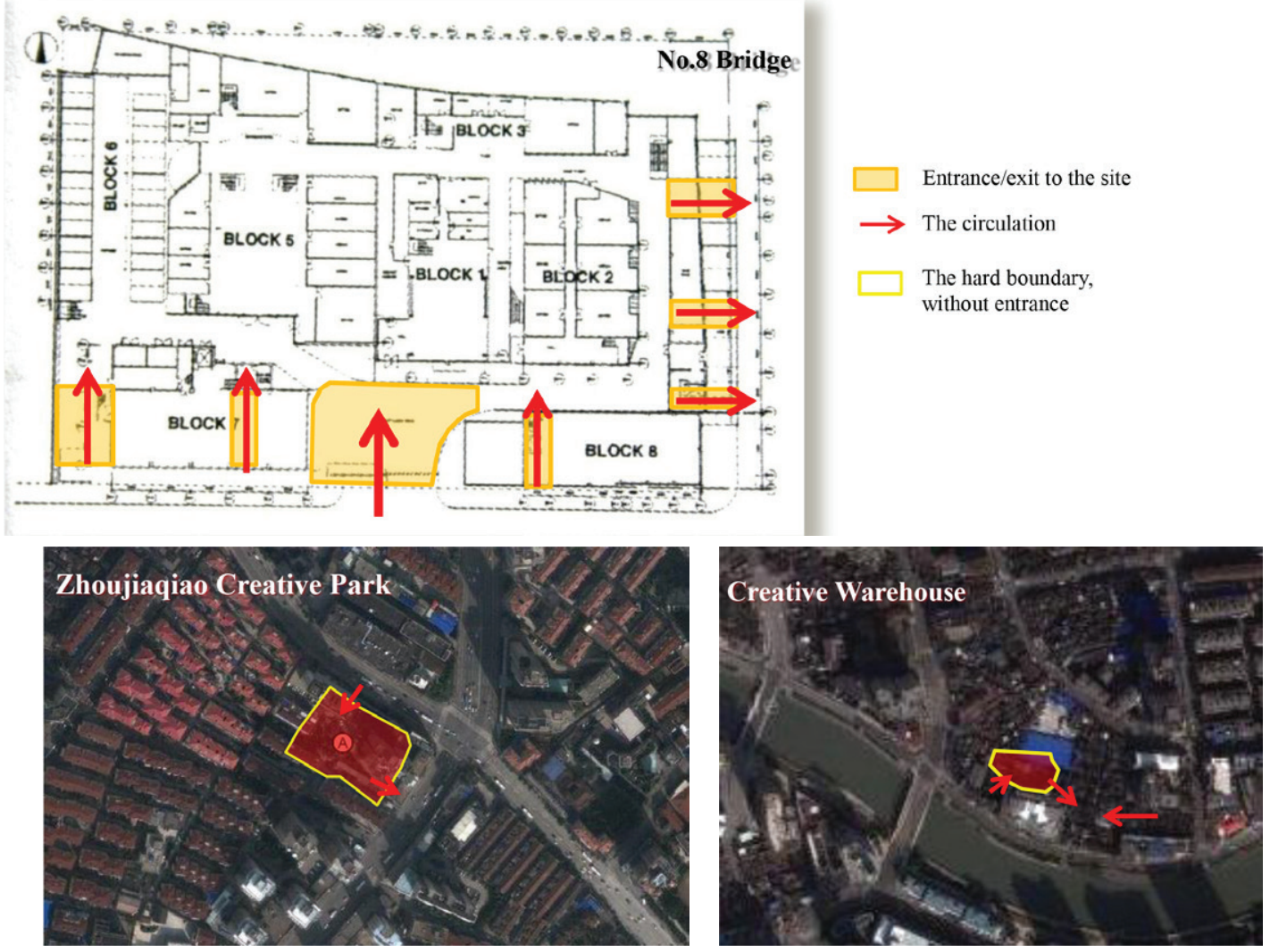

Figure 26.

A comparison of site accessibility of the four cases 


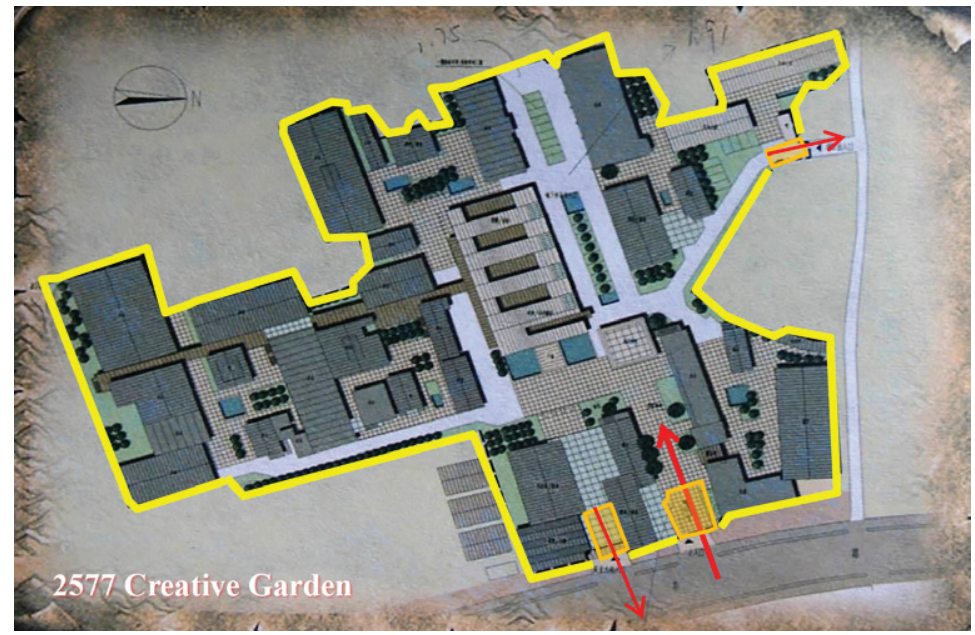

Figure 27. Lanes and entrances in the No. 8 Bridge
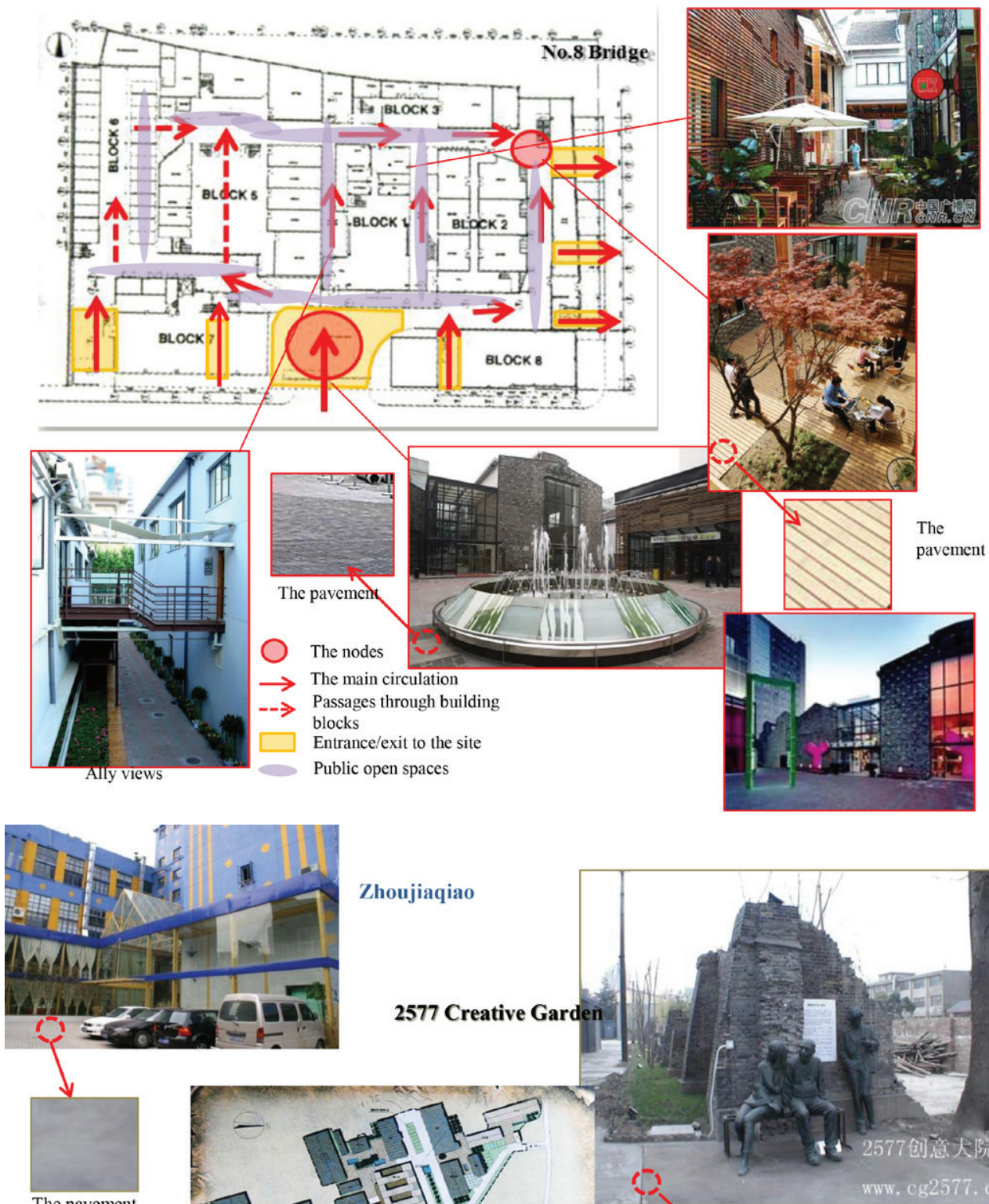

The pavement
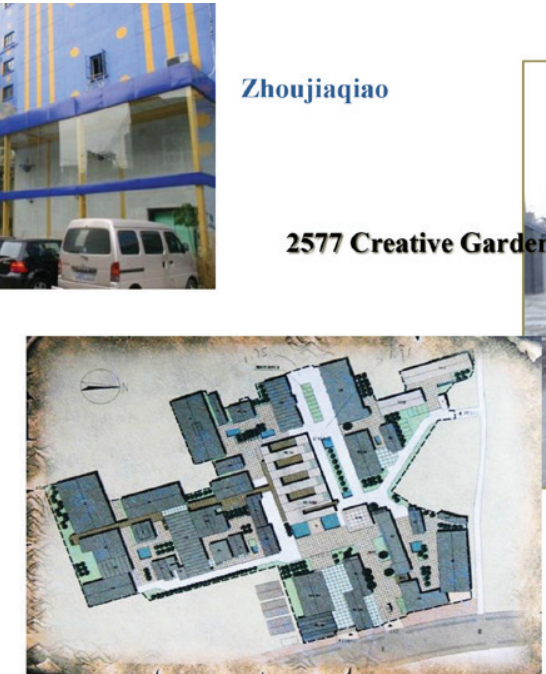

Zhoujiaqiao

2577 Creative Garden

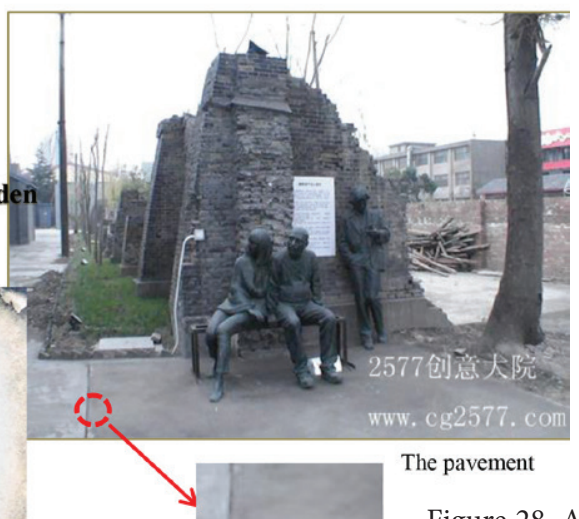

Figure 28. A comparison of open space quality, pavement, on-site circulation, etc. of three cases 


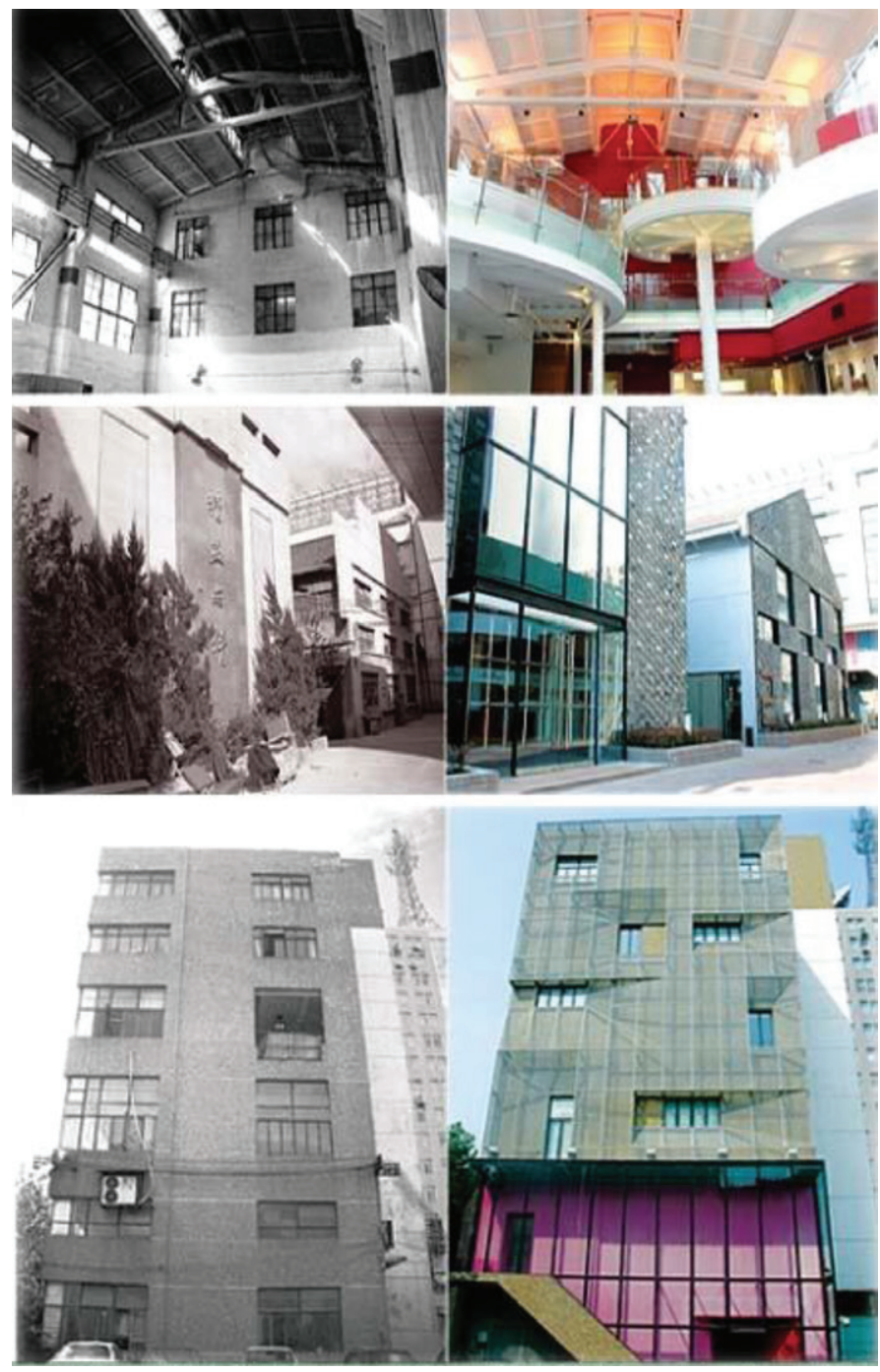

Figure 29. No. 8 Bridge designs in the building conversion
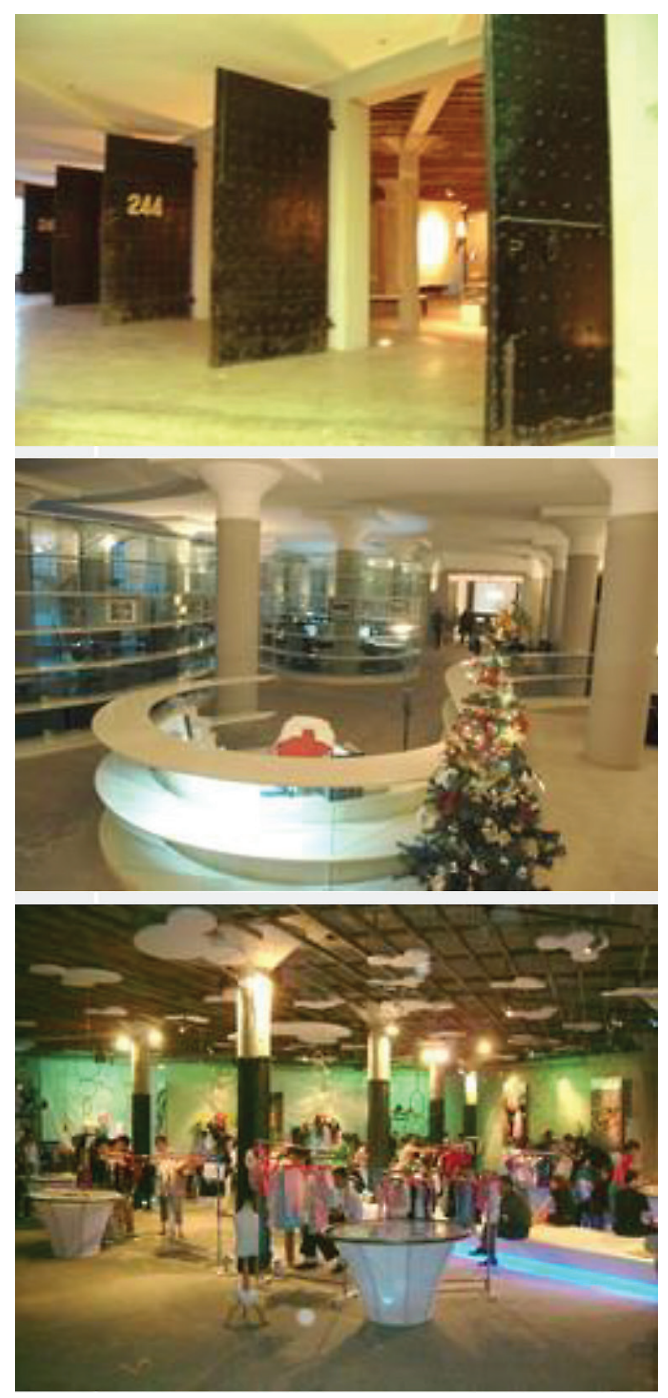

Figure 30. Interior designs of Creative Warehouse
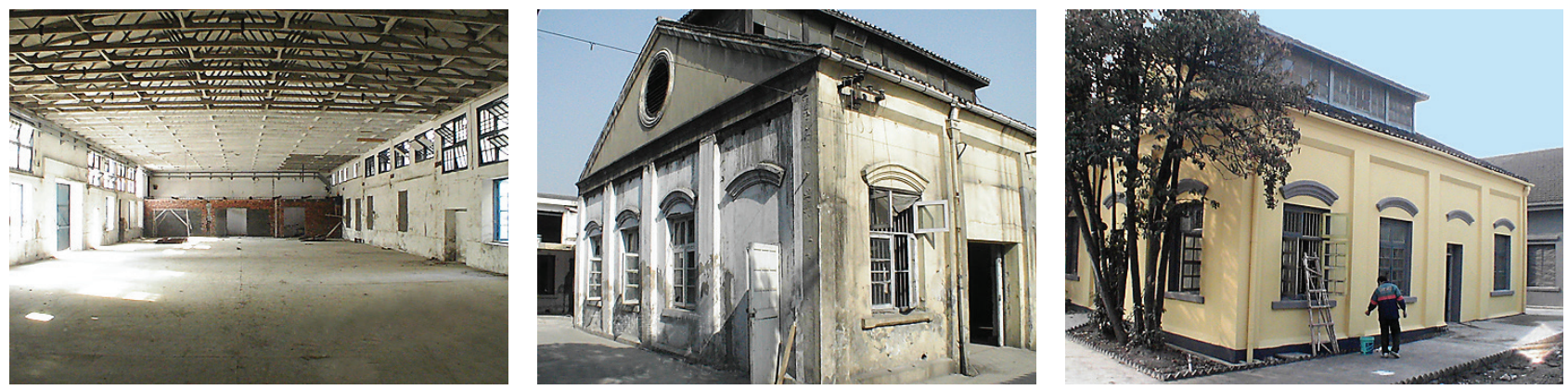

Figure 31. Improper application of new color paints to the preserved historic buildings, photo from www.cg2577.com 

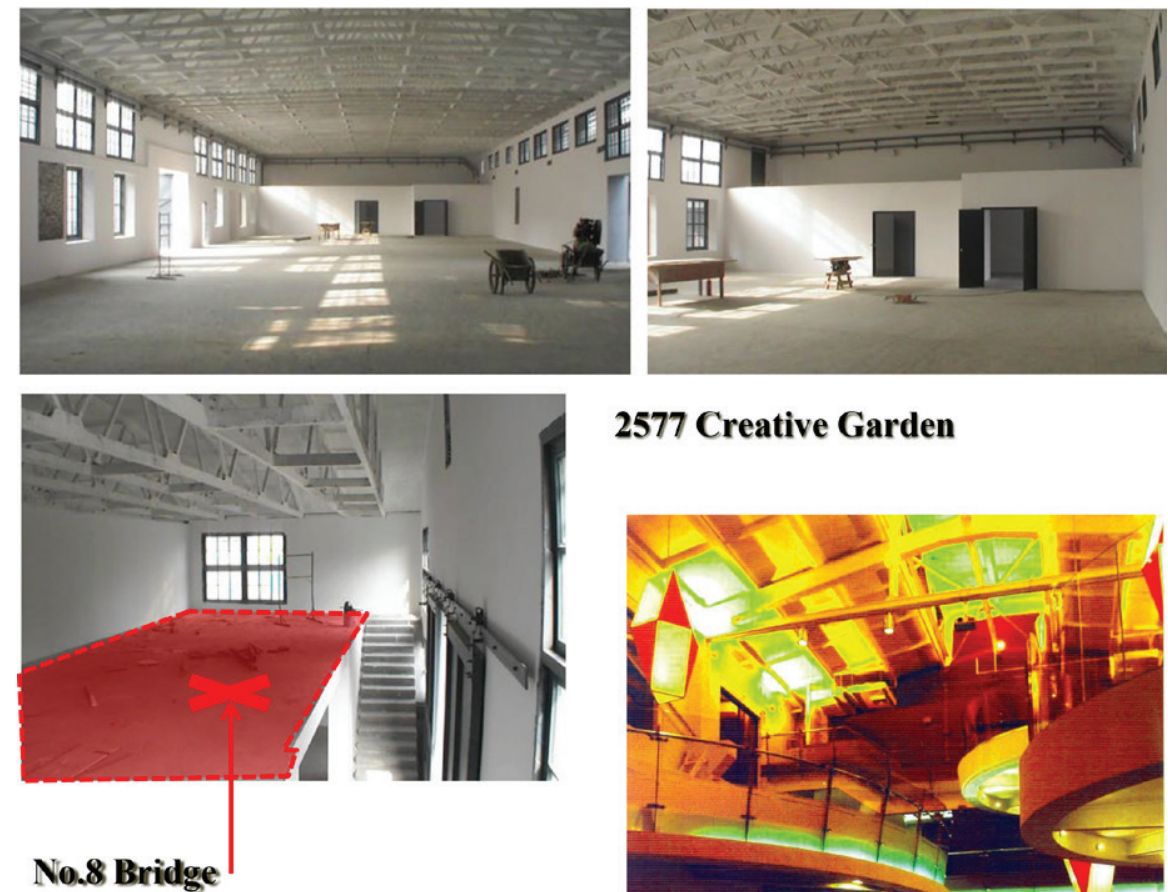

\section{Creative Garden}

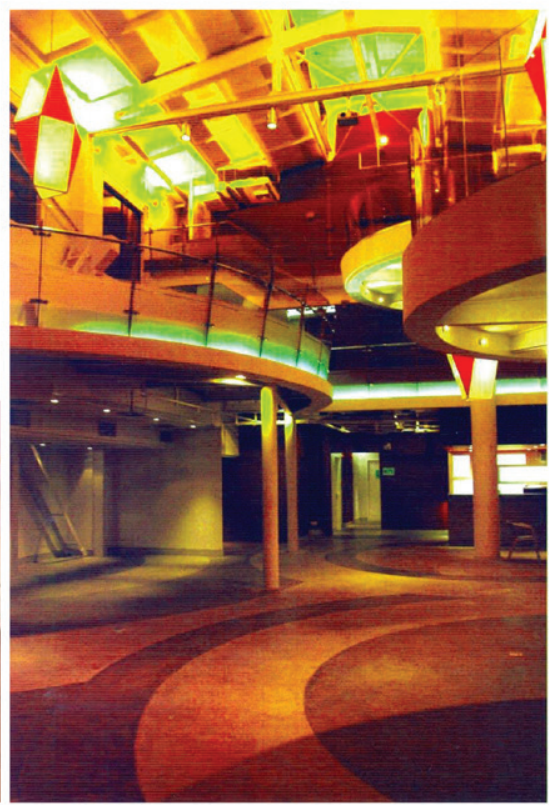

Figure 32. A comparison of interior partition between Creative Warehouse and No. 8 Bridge. The former partition obstructs people's view from below to seeing the historic ceiling. No. 8 Bridge tempers functional uses with artistic effects

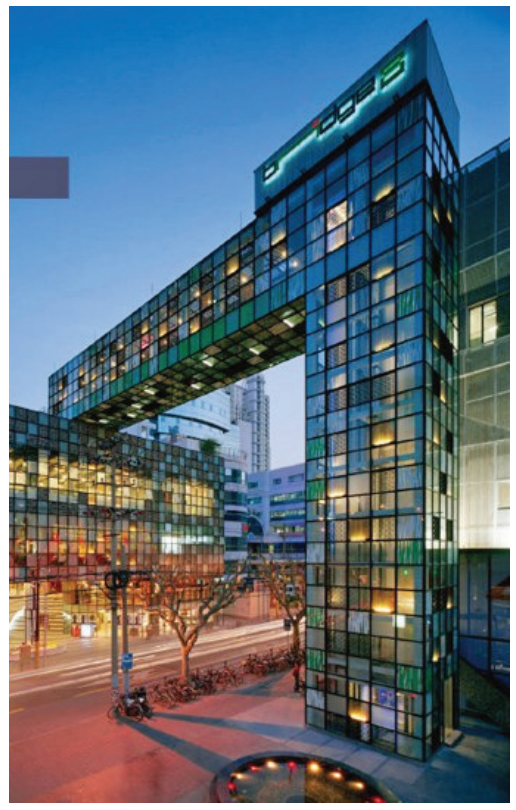

Figure 33. A new sky bridge in plan in No. 8 Bridge

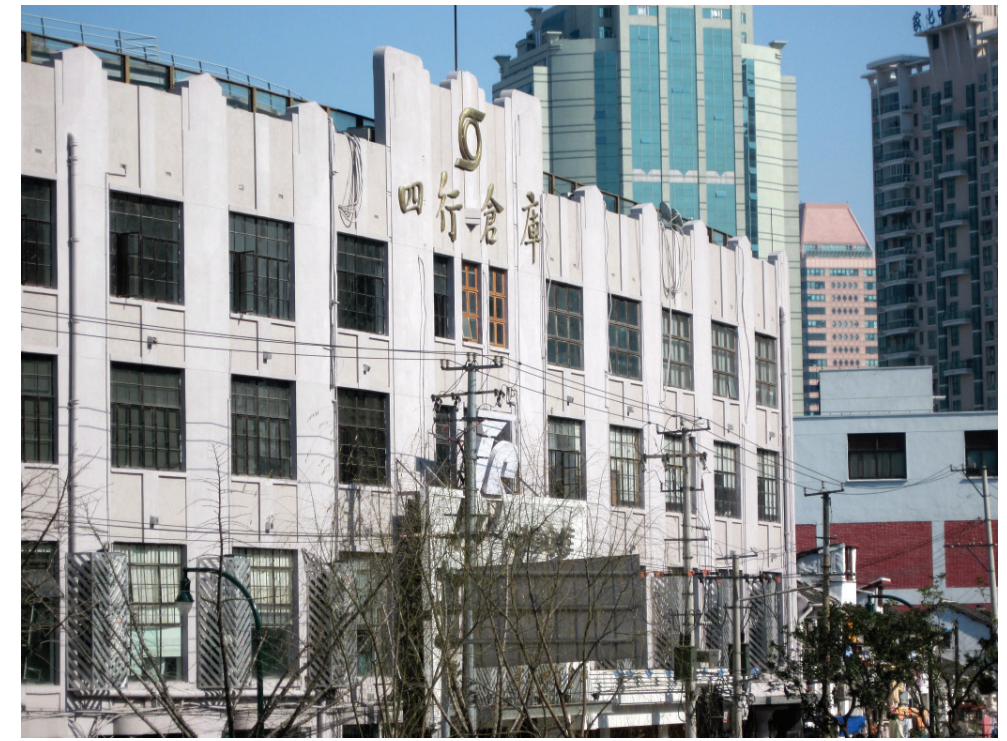

Figure 34. The external appearance of Creative Warehouse

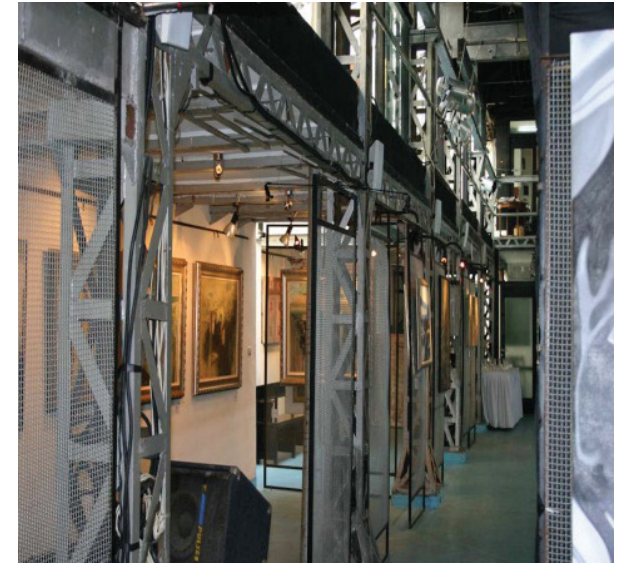

Figure 35. Zhoujiaqiao Creative Park 


\section{Conclusions}

The comprehensive evaluation approach based on Montgomery's theories of cultural quarters reveals the common features of the four creative industry parks in Shanghai. All the quarters performed poorly in certain indicators such as the strengths of small- and medium-sized companies, affordable spaces, availability of education/training services, and art development agencies and funding. These findings are consistent with the literature on both Chinese urban development and creative industry parks, which emphasize the pro-development or entrepreneurial stance of the state, wherein creative industry parks are treated as a newly emerged alternative type of office quarters for the tertiary industry in Shanghai. Prominent architectural and urban design merits (in comparison with previous office buildings/quarters) are consistent with the commercial nature of creative industry parks as a form of office properties. Evidently, fostering creativity and supporting smalland medium-scale creative industry companies are not on the agenda of the authorities (Zheng, 2010, 2011; Zheng \& Chan, 2013; O'Connor \& Gu, 2012; Keane, 2007, 2011).

Conversely, under the same political and social conditions, various developers in the private sector assumed the role of making quarter images and providing services with heterogeneities. Hong Kong and other overseas real estate developers, local real estate developers, and local stateowned enterprises, for example, adopted different design and managerial modes, which resulted in quality disparities across the four creative industry parks, as reflected by the indicators under the "built form" labels and part of the indicators under "activity" and "meaning." Hong Kong real estate developers employed Hong Kong or overseas architectural design services that applied the concept, design strategies, and architectural language of rehabilitation or loft living to the motif of indigenized Shanghai industrial buildings. The No. 8 Bridge is one of the earliest creative industry quarters that revitalized industrial buildings through rehabilitation. Architectural and urban designs in these cases highlight material contrasts and zeitgeist spirits, which are embedded in old materials and structures. Vibrant cultural activities and prosperous businesses, in addition to the history of the former manufacturing factory, also contributed to a sense of place. No. 8 Bridge is more successful according to the indicators for the three categories. Creative Warehouse comes next, whereas Zhoujiaqiao and the 2577 Creative Garden are relatively inferior in the dimensions related to responsive environment. In the latter two cases, design partially fails in both building function and image making, which indicates the relatively low quality of architectural design and place making, regardless of the role of the state and its policies. This result reveals that the disparity across the quarters is an indicator that the evaluation framework is generally effective.

The theoretical implication of this study is that the three evaluation frameworks for the assessment of cultural quarters are partially applicable to the creative industry parks in Shanghai. The three areas of the comprehensive evaluation framework based on Montgomery $(2003,2004)$ (i.e., activity, built environment, and meaning) can be retained in the Shanghai context. Moreover, the indicators that generally assess architecture design and place making are applicable to Shanghai. The other indicators that are associated with micro and small creative industry companies and cultural democracy, however, are inapplicable due to their inconsistencies with Chinese government policies. The empirical implication from this research is that the Shanghai government is advised to consider adjusting the cultural policies for creative industry parks or enacting specialized design guidelines for Shanghai's creative industry parks. For the long-term cultural production-led development toward prosperity, as opposed to cultural consumption-led approach, are desirable. For short-term practice, amendments on Montgomery's framework will help generate a fast evaluation instrument.

\section{Acknowledgements}

The author is grateful to Maria Francesca and Mark Pemble for organizing the special issue about urban Shanghai. I also thank the two anonymous reviewers and the journal editor Arnoldas Gabrenas for comments. Thanks also go to the following people for their contribution in an earlier stage of this research, including Stephen Lau, Leslie Lu, Desmond Hui, James Lago and Weijen Wang.

\section{Funding}

This research is funded by the University Research Council in Hong Kong (GRF: 14600215; 14621516).

\section{References}

Bentley, I. (1985). Responsive environments: a manual for designers. London: Architectural Press.

Canter, D. (1977). The psychology of place. London: Architectural Press.

Cartier, C. (2001). “Zone fever," the arable land debate, and real estate speculation: China's evolving land use regime and its geographical contradictions. Journal of Contemporary China, 10(28), 445-469. https://doi.org/10.1080/10670560120067135

Comedia, F., \& Gulbenkian, C. (1991). Out of hours: a study of economic, social and cultural life in twelve town centres in the UK. London: Comedia and Calouste Gulbenkian Foundation.

Common, R. (2000). The East Asia region: Do public-private partnerships make sense? In S. P. Osborne (Ed.), Public-private partnerships: theory and practice in international perspective (pp. 134-148). London, New York: Routledge.

Duan, W., \& Cui, H. (2006). Gongneng zhihuan: Deng Kunyan de Shanghai binjiang chuangyichanye yuan [Funcational update: The Waterfront Creative Park designed by Deng Kunyan in Shanghai]. Time Architecture, 2007(1), 62-67 (in Chinese).

Doratli, N. (2005). Revitalizing historic urban wuarters: a model for determining the most relevant strategic approach. European Planning Studies, 13(5), 749-772. https://doi.org/10.1080/09654310500139558

Edelman, S., \& Gaman, J. K. (2004). What not to build: do's and don'ts of exterior home design. N. J.: Creative Homeowner. 
Gong, T. (2006). Corruption and local governance: the double identity of Chinese local governments in market reform. The Pacific Review, 19(1), 95-102.

https://doi.org/10.1080/09512740500417723

Historic and Cultural City Research Centre. (2005). The Shanghai Taikang Road Historic Area Conservation and Reuse Concept Plan (Unpublished document, in Chinese). Tongji University.

Hsing, Y. T. (2006). Global capital and local land in China's urban real estate development. In F. L. Wu (Ed.), Globalization and the Chinese city (pp. 167-189). London, New York: Routledge.

Huang, J. (2005, June 3). Shanghai chuangyi cangku fangzu gaochu zhongdang xiezilou $30 \%$ [Rent charges of creative warehouses in Shanghai exceed that of the medium level office buildings by 30\%]. Guoji Jinrong Bao [International Finance], 1-10 (in Chinese).

Jacobs, J. (1960). The death and life of great American cities. Harmondsworth: Penguin Books.

Keane, M. (2007). Created in China: the great new leap forward. London, New York: Routledge. https://doi.org/10.4324/9780203937471

Keane, M. (2011). China's new creative clusters: Governance human capital and regional investment. London, New York: Routledge.

Kong, L., Gibson, C., Khoo, L. M., \& Semple, A. L. (2006). Knowledges of the creative economy: Towards a relational geography of diffusion and adaptation in Asia. Asia Pacific Viewpoint, 47(2), 174-194.

https://doi.org/10.1111/j.1467-8373.2006.00313.x

Lin, G. C. S. (2007). Reproducing spaces of Chinese urbanization: New city-based and land-centered urban transformation. Urban Studies, 44(9), 1827-1855. https://doi.org/10.1080/00420980701426673

Lin, N. (1995). Local market socialism: local corporatism in action in rural China. Theory and Society, 24, 301-354. https://doi.org/10.1007/BF00993350

Lynch, K. (1960). The image of the city. Cambridge, Mass.: MIT Press.

Montgomery, J. (2003). Cultural quarters as mechanisms for urban regeneration. Part 1: conceptualising cultural quarters. Planning, Practice \& Research, 18(4), 293-306. https://doi.org/10.1080/1561426042000215614

Montgomery, J. (2004). Cultural quarters as mechanisms for urban regeneration. Part 2: a review of four cultural quarters in the UK, Ireland and Australia. Planning, Practice \& Research, 19(1), 3-31. https://doi.org/10.1080/0269745042000246559
O'Connor, J., \& Gu, X. (2014). Creative industry clusters in Shanghai: A success story? International Journal of Cultural Policy, 20(1), 1-20. https://doi.org/10.1080/10286632.2012.740025

Olds, K. (2001). Globalization and urban change, capital, culture, and pacific Rim mega-projects. Oxford, New York: Oxford University Press.

Roodhouse, S. (2006). Cultural quarters: principles and practice. Bristol, UK, Portland.

Rogers, R. (1988, November). Brief in the future is rooted in the memory of the past. Royal Society of Arts Journal, 873-884.

Tang, B. S., \& Liu, S. C. (2001, June 15-17). Curses of arrogance: Why have Hong Kong developers been outperformed by local competitors in Mainland China? Paper presented at RC21 Conference of International Sociological Association Research Committee on Urban and Regional Development. Amsterdam, Holland.

Tiesdell, S., Oc, T., \& Heath, T. (1996). Revitalizing historic urban quarters. London: Butterworth-Architecture.

Xue, Q. L. C., \& Peng, N. (2006, June). An alternative modernity and metropolitan fantasy: an analysis of space of architecture by Japanese architects since 1980. Time Architecture, 124-129 (in Chinese).

Zhang, X. Q. (2005). Development of the Chinese housing market. In C. R. Ding, \& Y. Song (Eds.), Emerging land and housing markets in China (pp. 183-231). Cambridge, Mass.: Lincoln Institute of Land Policy.

Zheng, J. (2011). Creative industry cluster and the entrepreneurial city of Shanghai. Urban Studies, 48(16), 3553-3574. https://doi.org/10.1177/0042098011399593

Zheng, J. (2010). The entrepreneurial state in "creative industry cluster" development in Shanghai. Journal of Urban Affairs, 32(2), 143-170. https://doi.org/10.1111/j.1467-9906.2010.00498.x

Zheng, J., \& Chan, R. (2013). A property-led approach to cluster development: "Creative industry clusters" and creative industry networks in Shanghai. Town Planning Review, 84(5), 581608. https://doi.org/10.3828/tpr.2013.32

Zheng, J., \& Chan, R. (2014). The impact of "creative industry clusters" on cultural and creative industry development in Shanghai. City, Culture and Society, 5(1), 9-22. https://doi.org/10.1016/j.ccs.2013.08.001

Zhu, J. M. (2004). From land use right to land development right: institutional change in China's urban development. Urban Studies, 41(7), 1249-1267. https://doi.org/10.1080/0042098042000214770 